INTER NATIONAL MONETARY FUND
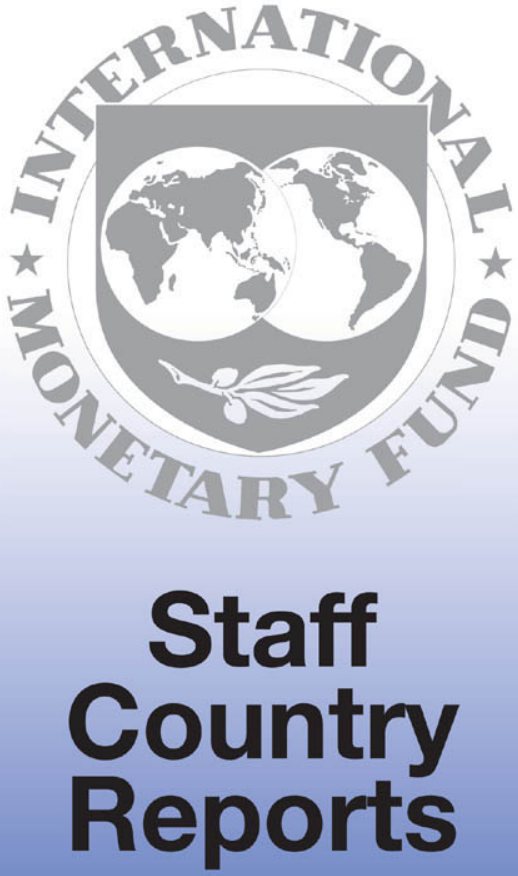


\title{
Singapore: 2010 Article IV Consultation-Staff Report; Staff Statement; Public Information Notice on the Executive Board Discussion; and Statement by the Executive Director for Singapore
}

The following documents have been released and are included in this package:

- $\quad$ The staff report, prepared by a staff team of the IMF, following discussions that ended on May 17, 2010, with the officials of Singapore on economic developments and policies. Based on information available at the time of these discussions, the staff report was completed on July 1, 2010. The views expressed in the staff report are those of the staff team and do not necessarily reflect the views of the Executive Board of the IMF.

- $\quad$ A staff statement.

- $\quad$ A Public Information Notice (PIN).

- $\quad$ A statement by the Executive Director for Singapore.

The policy of publication of staff reports and other documents allows for the deletion of market-sensitive information.

\author{
Copies of this report are available to the public from \\ International Monetary Fund $\bullet$ Publication Services \\ $70019^{\text {th }}$ Street, N.W. • Washington, D.C. 20431 \\ Telephone: (202) 623-7430 • Telefax: (202) 623-7201 \\ E-mail: publications@imf.org Internet: http://www.imf.org
}

\section{International Monetary Fund Washington, D.C.}




\section{INTERNATIONAL MONETARY FUND}

\section{SINGAPORE \\ Staff Report for the 2010 Article IV Consultation}

Prepared by the Staff Representatives for the 2010 Consultation with Singapore

Approved by Mahmood Pradhan and Dominique Desruelle

July 1,2010

- Context: Singapore's recession has been less deep and drawn out than feared at the time of the 2009 Article IV consultation, a year ago. A broad-based recovery is underway and the economy has regained all the output lost in the downturn. Policies have shifted out of crisis mode and smooth exits from extraordinary support have been achieved.

- Discussions: May 11-17, 2010, with Senior Minister Goh Chok Tong, Minister for Finance Tharman Shanmugaratnam, Acting Managing Director of the Monetary Authority of Singapore (MAS) Ong Chong Tee, other senior officials, and representatives of the private sector.

- Team: Messrs. Zanello (head), Dodzin, Abdel-Rahman, Nabar (all APD), and Balakrishnan (Resident Representative). Mr. Chua (OED) also participated in the meetings.

- Mission focus: The nature of the recovery. Policies to support the expansion and strengthen medium-term prospects. The medium-term evolution of the current account. The likely impact of Basel III.

- Policy dialog: For a description of policy issues discussed in the 2009 Article IV consultation, see http://www.imf.org/external/pubs/cat/longres.cfm?sk=23226.0.

- Exchange rate system: Singapore has accepted the obligations of Article VIII, Sections 2, 3, and 4. The exchange system is free of restrictions on the making of payments and transfers for current international transactions. Solely because of classification changes, the de facto exchange rate arrangement, previously a floating regime, is now classified as "other managed."

- ROSCs: A fiscal ROSC remains a priority for the authorities. Its exact timing is likely to be decided next year. A data ROSC could be considered at that time.

- Data: Adequate for surveillance. 


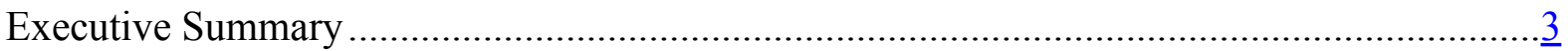

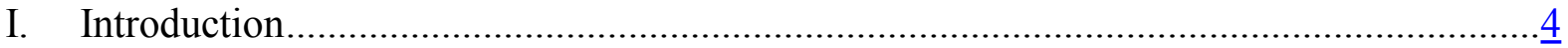

II. Macroeconomic and Financial Developments ................................................................

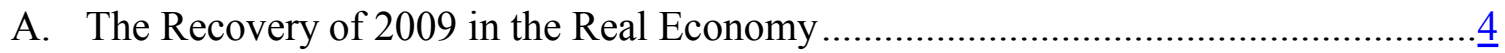

B. The Recovery of 2009 in the Financial Sector .....................................................

C. Behind the Recovery...................................................................................

III. Policy Developments ..............................................................................................

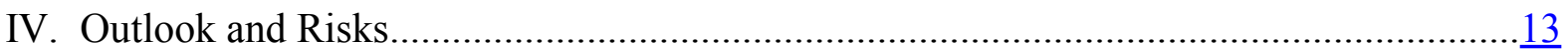

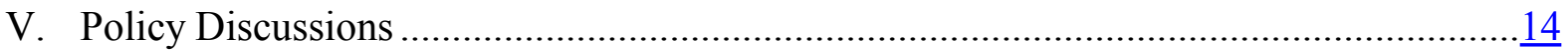

A. Macroeconomic Policies on the Recovery Path ....................................................14

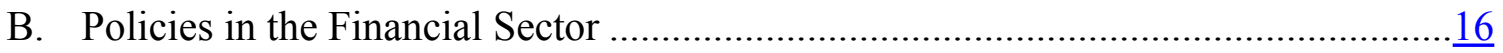

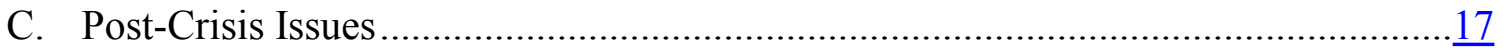

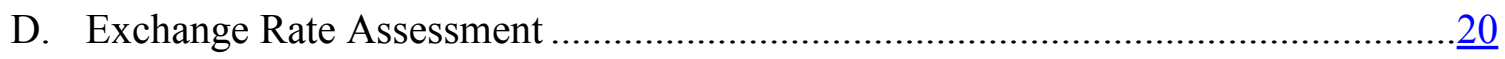

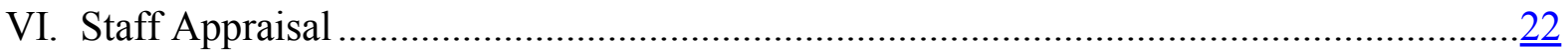

Boxes

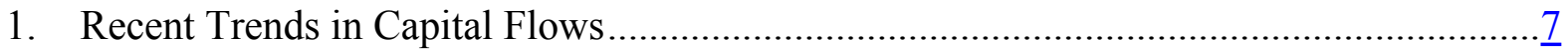

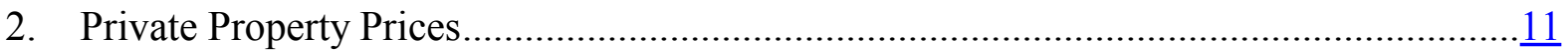

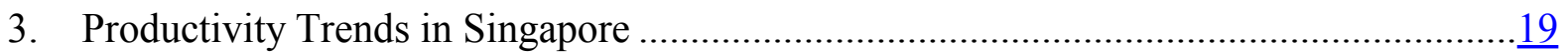

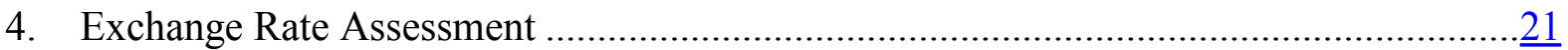

Figures

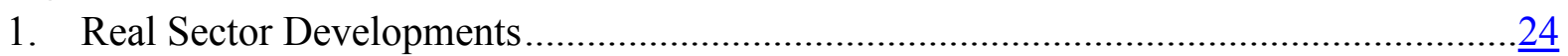

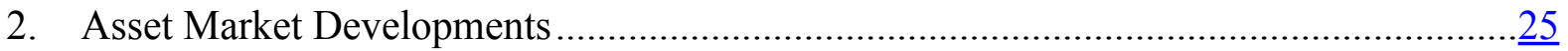

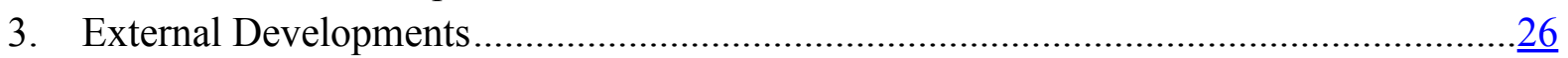

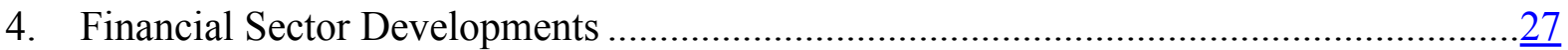

Tables

1. Selected Economic and Financial Indicators, 2005-11 ...............................................

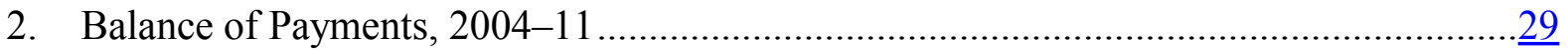

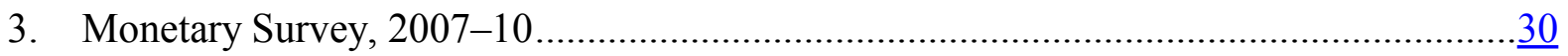

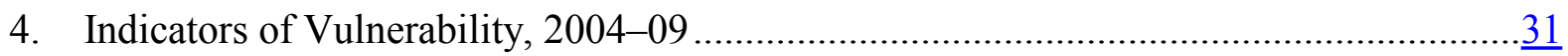

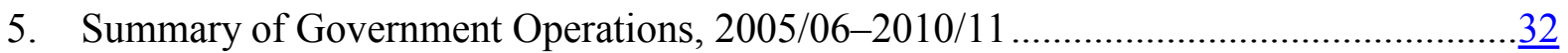

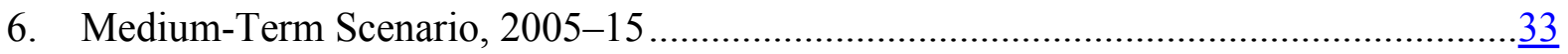

7. Financial Soundness Indicators: Local Banking Sector, 2005-09...................................34 


\section{EXECUTIVE SUMMARY}

Background. Thanks to strong policies, resilient markets, and an improved external environment, the 2008-09 recession turned out less deep than feared. A broad-based expansion is now on. Output losses have been recouped and medium-term issues are again at the top of the policy agenda.

Policy issues. Macroeconomic management started to transition out of crisis-relief mode late last year. Policy normalization has by now been achieved. Discussions centered on the requirements to sustain non-inflationary growth and mitigate external and internal risks, as well as on topics that have gained prominence in the international post-crisis debate.

Monetary policy. The monetary settings are broadly appropriate. Staff and authorities agreed that monetary policy should stay the course, absent a significant deterioration of the outlook for growth and inflation. Exuberance in some segments of the property markets does not seem to portend a boom-bust cycle in real estate. Macroprudential tools have nonetheless been deployed preemptively to curb speculative excesses.

Fiscal policy. Like the stimulus of last year, the withdrawal of fiscal support in the 2010 budget has been timely and well calibrated. The fiscal stance is now close to neutral and in tune with internal balance. The 2010 budget appropriately focuses on supply-side measures to promote productivity growth.

Financial sector. The domestic financial sector emerged largely unscathed from the global financial crisis, thanks to sound supervision and risk management systems. There was agreement that Singapore's financial sector is strong. Plans (in coordination with Malaysia and Hong Kong SAR) to unwind by year-end the blanket deposit guarantee and move to a system with higher deposit coverage are underway. In the view of the authorities, the impact of Basel III requirements is not expected to be too onerous for Singaporean banks, which are already well capitalized, have stable funding sources, and whose risky assets are well provisioned.

Exchange rate. The Singapore dollar in real effective terms is somewhat weaker than its medium-term equilibrium. Singapore's exchange rate regime continues to serve the economy well and the MAS' exchange-rate centered monetary framework has been an important source of stability in times of economic turbulence. 


\section{INTRODUCTION}

1. Context. A year ago, Singapore seemed in the midst of its worst recession ever. Collapsing global demand and market sentiment were taking a toll on core domestic activities. ${ }^{1}$ Policy responses, although exceptionally large and diversified, were not expected to fully offset the impact of the external shocks. All considered, the staff and the authorities were projecting a GDP contraction of about 8 percent for the year at the time of the 2009 Article IV consultation. Defying predictions, the 2008-09 recession turned out to be less deep than feared. A broad-based expansion is now on. Output losses have been recouped and medium-term issues are again at the top of the policy agenda.

2. Focus of the mission. The 2010 Article IV discussions centered on the policies to sustain non-inflationary growth and mitigate risks, including those related to capital flows and exuberant property markets. Topics that have gained prominence in the international policy debate after the crisis - Basel III, self-insurance through reserve accumulation, the design of social protection, and productivity-boosting reforms - were also covered in a Singaporean context. The starting point was a comparative anatomy of the conjuncture from both a historical and a regional perspective.

\section{MACROECONOMiC AND FinANCIAL DEVELOPMENTS}

\section{A. The Recovery of 2009 in the Real Economy}

3. Context. GDP contracted by about $1 \frac{1}{4}$ percent in 2009 , an outcome much milder than anticipated. The recession was the third since the Asia crisis and marked the end of a decade when output volatility increased and the average annual growth rate dropped to about 5 percent from about $71 / 2$ percent in the 1990 s.

4. GDP growth. Activity started to shrink in the second quarter of 2008. At its low mark a year later, GDP was 9 percent lower than pre-crisis, the biggest output decline in twenty years. The recovery has been as swift as the contraction. Strong countercyclical policies supported domestic demand while the turning of the inventory cycle gave a boost to manufacturing (especially of electronic goods, which account for about half of Singapore's non-oil domestic exports). At the same time, more stable

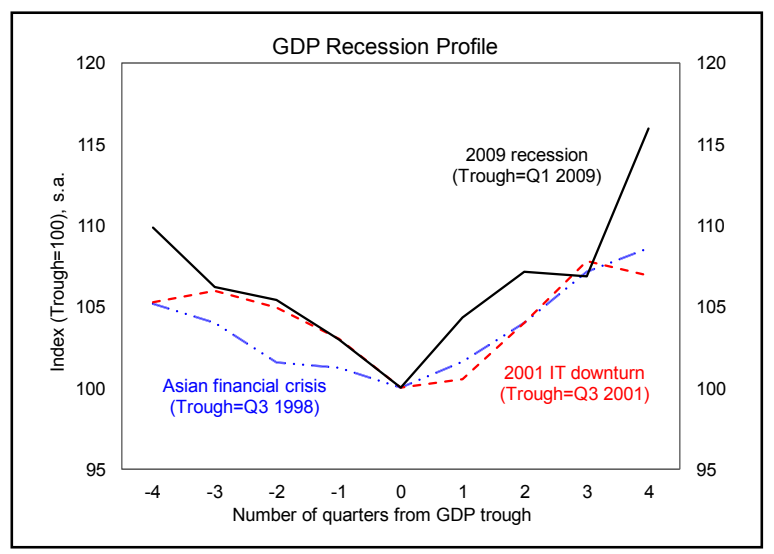

\footnotetext{
${ }^{1}$ Trade-oriented sectors and financial services account for about three-quarters of value added.
} 
global market conditions supported financial services. Growth has been double-digit for three of the last four quarters, reaching nearly 39 percent (q/q s.a.a.r.) in the first quarter of this year. From a historical perspective, this upswing has been more vigorous than those following the 2001 dotcom crash and the 1997-98 Asia crisis: GDP was some 16 percent higher four quarters after the trough, compared to 5-10 percent in the previous downturns.

5. Inflation. Price dynamics have mirrored those of output. CPI inflation declined quickly and turned negative in the second half of 2009. With dissipating base effects, rising fuel and transport costs, and growth above potential, price pressures have resurfaced since early 2010 - and the CPI is back to its previous peak, three quarters on. By contrast, it took about nine quarters in earlier recoveries for the price level to regain the ground lost. The latest readings show sustained upward momentum in headline inflation (in May, 0.6 percent $\mathrm{m} / \mathrm{m}$

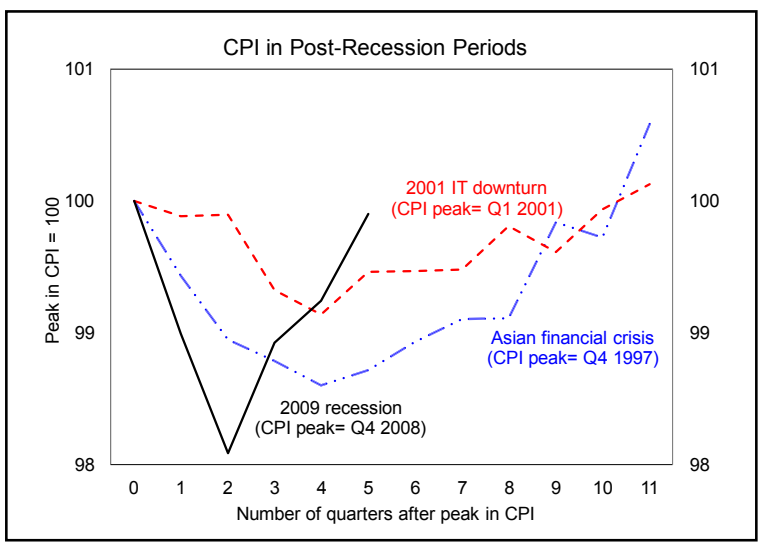
and over 3 percent $y / y$ ). However, core inflation (as defined by the MAS) remains low and demand-driven price pressures are not an immediate policy concern.

6. Labor markets. Labor markets too have proved more resilient this time around than in previous recessions. Employment fell later in the cycle and bounced back faster. In fact, job creation in the second half of 2009 more than offset losses in the first half of the year, and the unemployment rate for residents is near pre-crisis levels. In contrast, net job losses persisted for over one year during the Asian crisis and the IT downturn. The resilience of employment reflects both policies (e.g., job subsidies in the 2009 budget) and structural changes

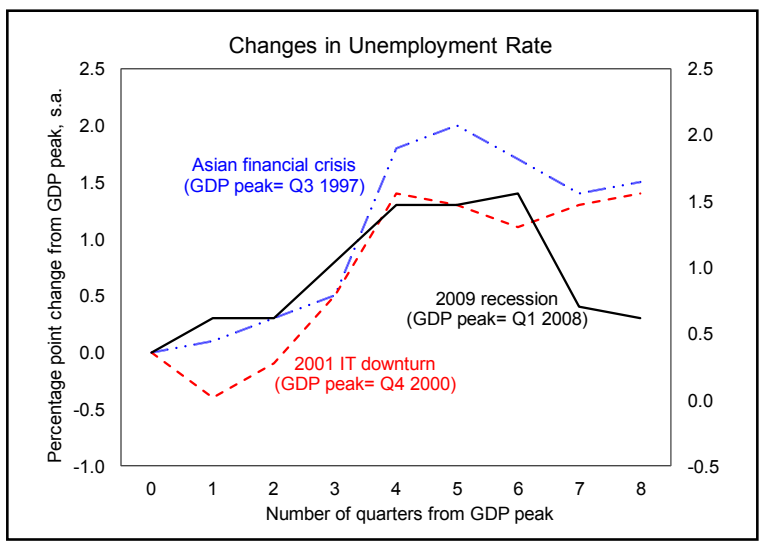
(e.g., greater downward flexibility in wages). ${ }^{2}$ With higher levies on foreign workers in the period ahead, the roll back of the job subsidies, and the likely reversal of last year's cuts in hours worked and compensation, wage pressures are picking up.

\footnotetext{
${ }^{2}$ The FY 2009 (ending in March) budget introduced the Resilience Package, aimed at blunting the effects of the downturn and strengthening longer-term prospects for Singapore. The package amounted to $\mathrm{S} \$ 20.5$ billion (about 8 percent of GDP). An innovative element was the Jobs Credit Scheme. It provided an incentive for companies to maintain or increase their Singaporean workforce, by giving them grants of 12 percent of
}

(continued...) 
7. Balance of payments. Singapore has felt the impact of the global recession primarily through the trade channel. From peak to trough, non-oil domestic exports fell by close to 30 percent. Their revival has initially been as sluggish as that from the IT recession but it has gained momentum since late last year. Electronics exports in particular have been boosted by consumer demand in China and corporate IT investment in the United States. Capital flows have also recovered, suggesting a return of foreign investors' interest in Singapore-dollar assets, spurred by improved prospects for the domestic and regional economies (Box 1). Official reserves, which were drawn down early in the crisis, have been on an uptrend since March 2009 and stood at about US\$198 billion at end-May 2010, after the MAS absorbed inflows in accordance with its

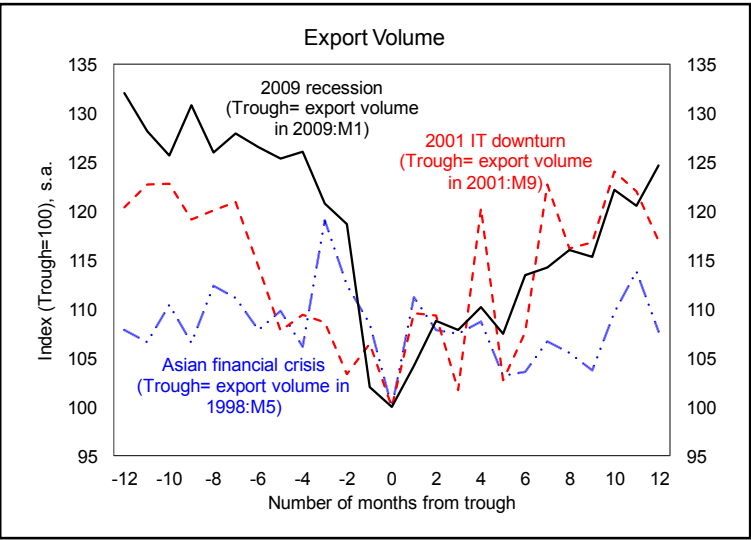
exchange rate-centered monetary framework.

8. Cross-country perspective. Singapore's output trajectory has been broadly similar to those of regional peers, which all experienced a V-shaped cycle (Figure). The depth of the contraction was however somewhat greater than average, reflecting the economy's extraordinary openness (trade is about three times GDP) and specialization in cyclically-sensitive goods and services. Where Singapore stands apart from the rest is perhaps in the evolution of employment and wages, suggesting the critical role played by active labor-market policies, flexible wage-setting mechanisms, and government guarantees in supporting households' confidence and income, firms' access to credit, and - ultimatelydomestic demand.
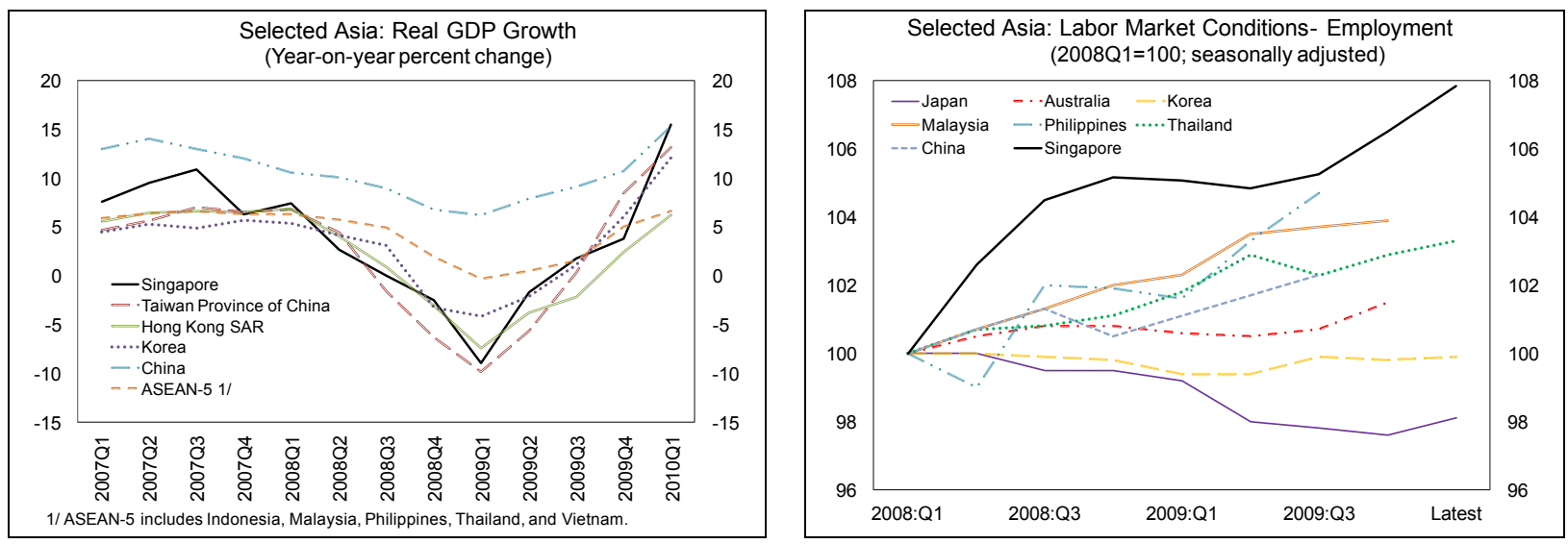

employee's wages, up to a specified maximum. This scheme is estimated to have lowered labor costs by about 9 percent. Another element of the package was the Special Risk-Sharing Initiative, under which the government assumed 80 percent of loan-loss risk to encourage bank lending to SMEs. 


\section{Box 1. Singapore: Recent Trends in Capital Flows}

Historically, Singapore has experienced significant net capital outflow, the counterpart of persistent current account surpluses. Official flows have constituted the bulk of net outflows, reflecting mostly foreign asset accumulation by Singapore's sovereign wealth funds. Private flows excluding FDI have also been negative. Net FDI flows, on the other hand, have been consistently positive, the result of Singapore's favorable business climate for multinational corporations.

\section{Private capital flows have rebounded since mid-2009.}

- Loans, trade financing, and other nonportfolio flows have recovered strongly. Banks were major recipients of these flows in the last quarter of 2009 and the first of 2010.

- Net FDI flows have also picked up, although they never contracted significantly during the crisis.

- Private portfolio investment, however, has continued to flow out, but at a declining rate.

These developments are consistent with supply-side indicators that point to a recovering bank activity but some lingering fragility in other sentiment-sensitive segments of Singapore's financial industry, including asset management.

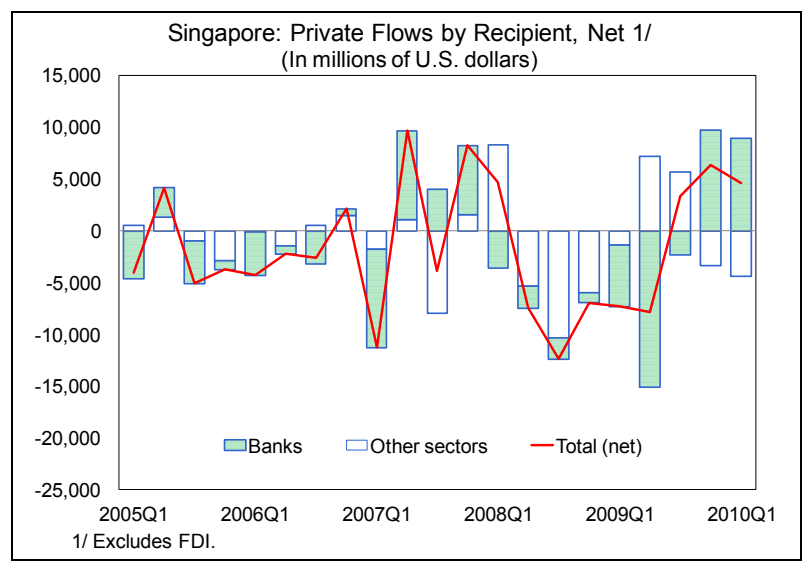

Singapore: Capital Flows

(Period average, in percent of GDP)

\begin{tabular}{lccc}
\hline & $1993-09$ & $2001-09$ & $2008-09$ \\
\hline Official & -11.9 & -11.8 & -12.4 \\
Private, excluding FDI & -4.8 & -6.1 & -7.4 \\
Of which: & & & \\
$\quad$ Banks & 0.0 & -1.7 & -6.2 \\
$\quad$ Nonbank private 1/ & -4.8 & -4.4 & -1.2 \\
FDI & 5.6 & 5.4 & 8.0 \\
Total private & 0.8 & -0.7 & 0.6 \\
Memorandum item: & & & \\
$\quad$ Current account & 17.2 & 19.3 & 18.1 \\
\hline
\end{tabular}

Sources: Singstat; and IMF staff estimates.

1/ Include some official liabilities.

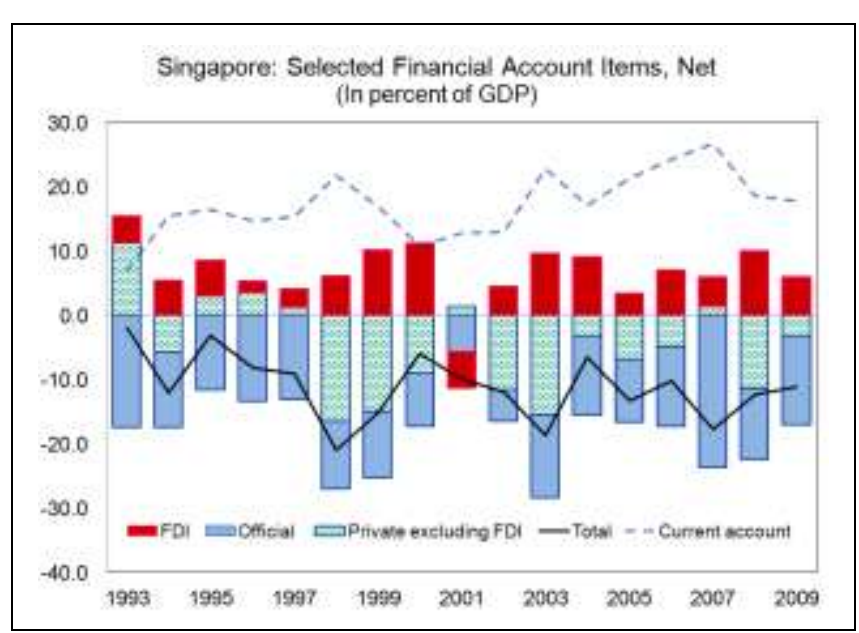




\section{B. The Recovery of 2009 in the Financial Sector}

9. Context. Although tested, Singapore's financial system withstood the world recession well. As global market volatility subsided, financial activities staged a rapid recovery beginning in early 2009. Banking and insurance led the way, while brokerage and wealth management were slower in posting gains. More recently, momentum in some financial services has softened amidst investors' concerns about global prospects.

10. Money markets. Singapore's money markets experienced liquidity pressures at the onset of the crisis but never seized up. Reflecting extraordinary monetary support at home and abroad, the three-month interbank rate (SIBOR) stayed at an all-time low of about 0.7 percent since January 2009. ${ }^{3}$ The Swap Offered Rates (SOR) bottomed out with the MAS' return in April to a targeted trend appreciation of the Singapore dollar in effective terms, but recent market concerns about sovereign credit risks in Europe have pushed them up somewhat. Compared to

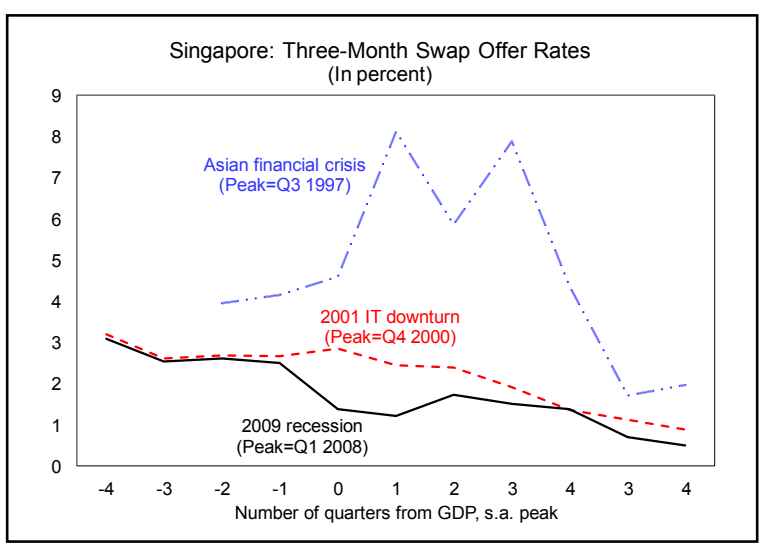
previous episodes, interest rates remain much lower for this stage of the cycle, with possible implications for asset prices.

11. Bank credit. The credit cycle turned faster during this recession than in earlier ones. Singapore dollar loans to nonbank customers reached a low point in April 2009. They are now above pre-Lehman levels. By contrast, in the aftermath of the Asia crisis, domestic currency lending continued to contract for more than 4 quarters after GDP crested. The current uptrend in Singapore dollar intermediation masks, however, different speeds of recovery in different markets: consumer loans (mostly mortgages) have been

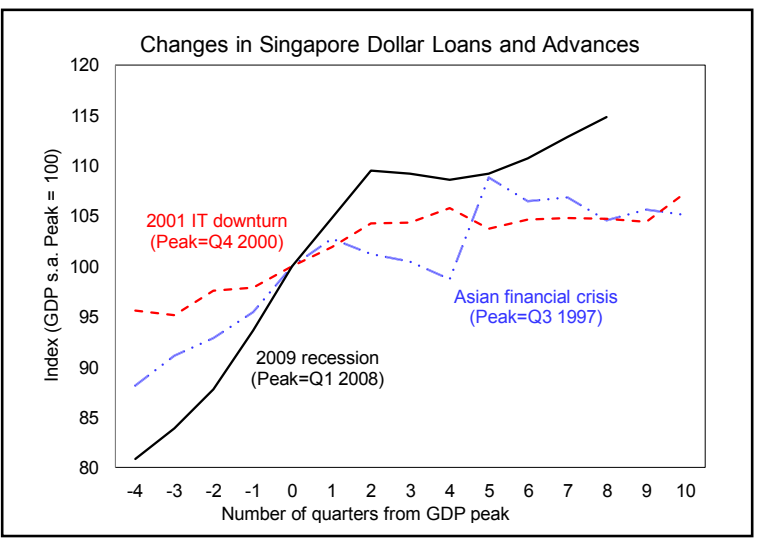

\footnotetext{
${ }^{3}$ The SIBOR is a reference rate based on interest rates offered by banks for unsecured lending of Singapore dollars in the wholesale money market. The SOR represents the effective cost of borrowing Singapore dollars synthetically by borrowing U.S. dollars for three months and swapping them for Singapore dollars. It is more volatile than SIBOR because the exchange rate and U.S. money market rates fluctuate more. A steeper slope of the MAS' policy band is reflected in the U.S. dollar-Singapore dollar forwards and in lower SOR fixings, consistent with covered interest parity.
} 
expanding briskly but credit to businesses is still below peak. Regarding the latter, limited credit access does not seem to be a factor, as suggested by the tapering off of loan approvals under the government credit guarantee scheme. The deployment of retained earnings to reduce leverage is also holding back foreign currency nonbank lending in the Asian Dollar Market. Offshore interbank activity, which is more tied to developments in advanced economies, is now registering upticks. However, volatile market sentiment is still in the way of a steady rise in volumes.

12. Capital markets. In the sell-off at the heart of global deleveraging, the Singapore equity market fell some 60 percent, reaching bottom in early 2009. As international financial conditions stabilized and portfolio inflows resumed, losses have been clawed back - in Singapore as elsewhere-but not as fast as after the Asia crisis, and price earnings ratios remain below long-term averages. The corporate debt market followed regional trends, too: issuance has started to pick up, yet it remains below its pre-crisis level, with little recovery in the

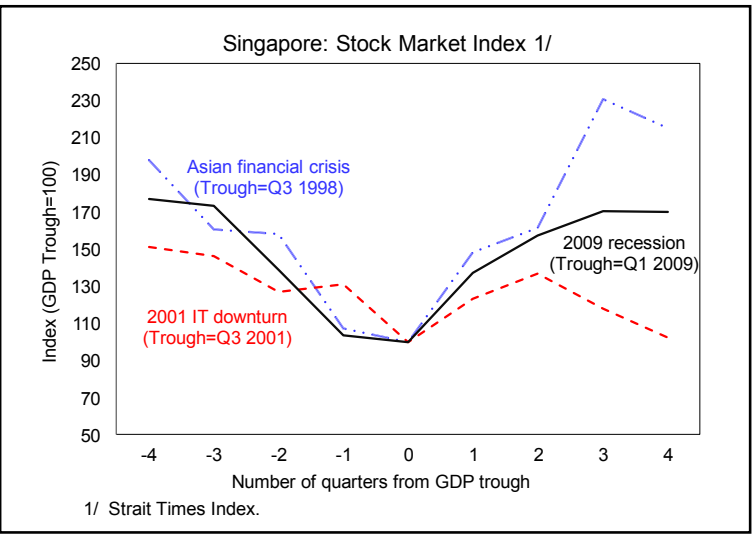
foreign currency segment. Reflecting changes in the monetary stance and the outlook, the yield curve has shifted down and steepened.

13. Foreign exchange market. Daily turnover in the foreign exchange market - the fifth largest in the world-shrunk post-Lehman as financial institutions hoarded cash and U.S. dollar liquidity evaporated. It was 15 percent lower than a year earlier by end 2009. With the recovery of trade and sentiment about regional prospects, volumes rebounded, supporting activity in this important segment of Singapore's financial sector. By March 2010, they had returned to pre-crisis levels. The Singapore dollar has

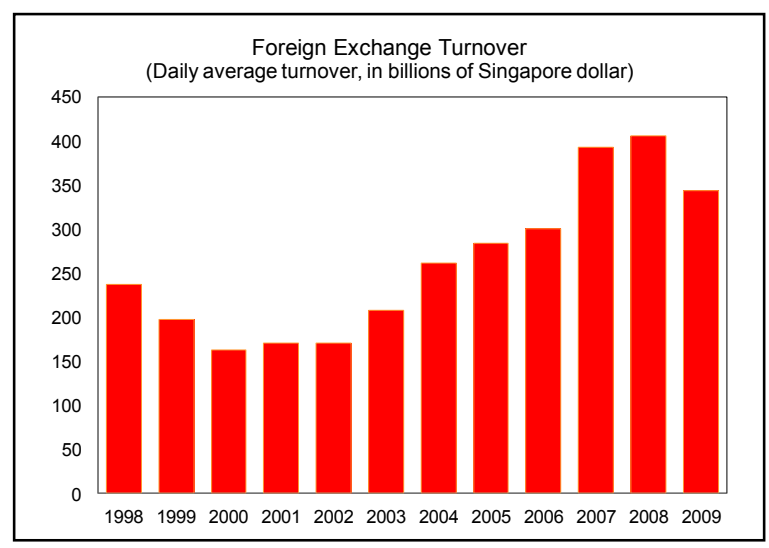
strengthened over the last year, but the trend has been punctuated by bouts of volatility. In nominal effective terms, it was 5 percent higher in May than at the time of the 2009 Article IV consultation. 
14. Property markets. The recovery of 2009 has been at its most dramatic in Singapore's private property market (Box 2). After a prolonged stagnation, private house prices (as opposed to the prices of the publicly built dwellings where some 80 percent of Singaporeans live) started to increase in 2006, crested in mid 2008, and fell swiftly with the downturn. The rebound has mirrored the downward correction. This roller coaster ride has prompted concerns of a boom-bust cycle. An array of macroprudential and supply-side measures have been deployed by the authorities to preempt speculative excesses. As a result,

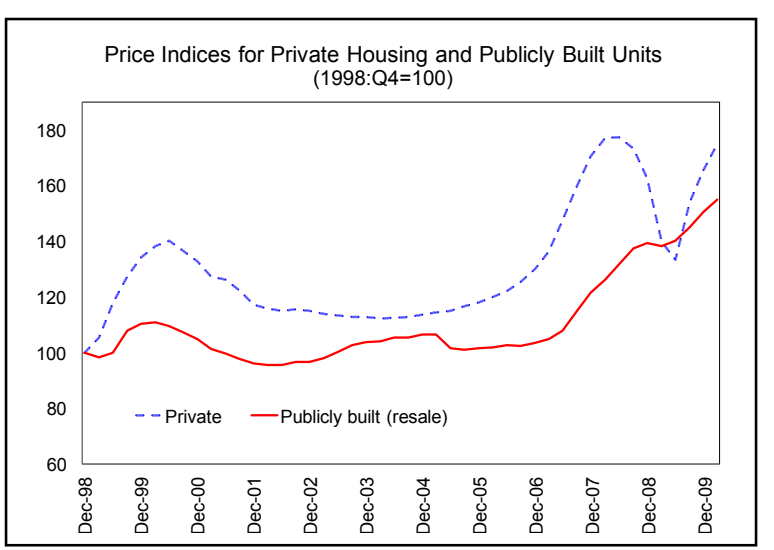
prices of private homes have stabilized recently, and the number of transactions has declined.

15. Cross-country perspective. As elsewhere in the region, Singapore's recovery of 2009 has brought in its wake improved equity valuations, an expansion of credit to households, renewed corporate issuance, and a resurgence of capital inflows. Like many regional currencies, the Singapore dollar has moved closer to its early 2008 level against the U.S. dollar and on a multilateral basis. Singapore's status as a major funding and financial center for Southeast Asia suggests a comparison with Hong Kong SAR. Both economies saw the pressures created by the failure of Lehman Brothers abate in early 2009 , as a result of home-grown

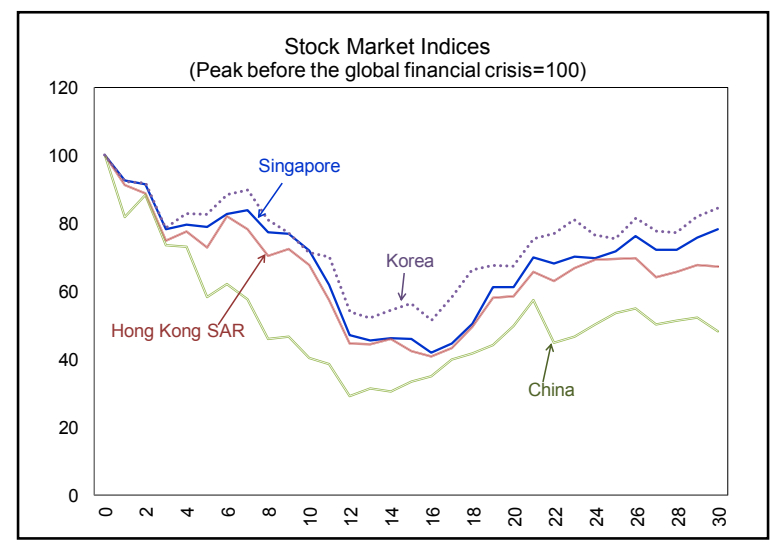
policies and improving conditions in global capital markets. Both economies had similar trajectories for equity and house prices in the upswing, with exuberance in some segments of the property market. (Tellingly, the macroprudential responses to prevent a bubble have been alike). A key difference, of course, is that Hong Kong SAR is inherently more exposed on its recovery path to inward spillovers from abundant U.S. dollar liquidity or the rapid expansion in Mainland China, because of the exchange rate peg. By contrast, the risk for a credit-asset price cycle is lower in Singapore, where the MAS' policy framework provides a measure of monetary independence.

\section{Behind the Recovery}

16. Context. Both external and internal developments have limited the severity of Singapore's downturn and set the stage for the expansion underway. 


\section{Box 2. Singapore: Private Property Prices}

After remaining stable for most of the 2000s, property prices have been volatile over the past year. After losing nearly a quarter of its value from the peak in the second quarter of 2008 through to the trough a year later, the private residential property index has regained almost all of the lost ground.

Private properties experienced a more pronounced cycle than publicly built units. The difference is in part due to the large influx of skilled foreign workers bidding up prices during 2006-08. During this period, Singapore's labor force expanded by about 8 percent annually with the number of foreign workers surging by nearly 20 percent each year. (Foreign workers now account for over one-third of the labor force). The large peak-to-trough decline in 2008 was driven by the expectation that the global slump would curb the inflow of foreign employees, particularly in financial services.

\section{The recovery in property prices has been} faster than in the previous cycles. By this stage in the post-Asian crisis recovery, property prices were 17 percent above their trough ( 24 percent in the current cycle).

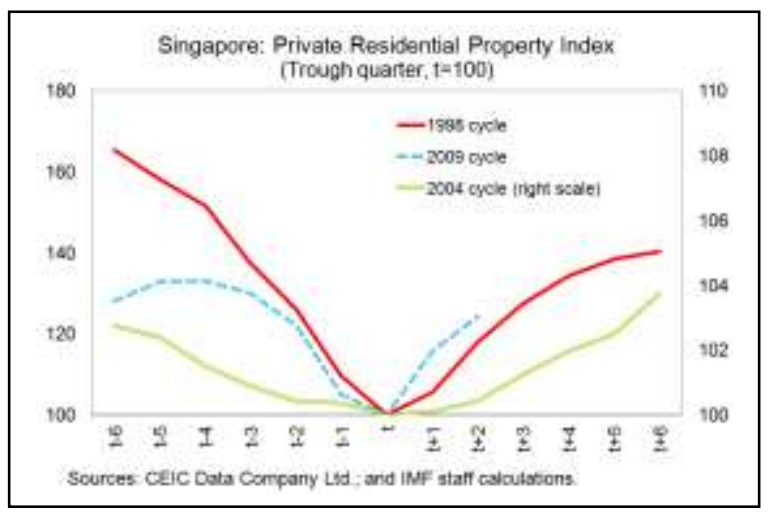
Looking at the overall property market across peers, prices have risen at broadly the same pace in Hong Kong SAR, although the cycle took longer to turn in Singapore.

\section{The authorities have taken several pre-emptive measures since September 2009 to} forestall excesses. Some of the initiatives are intended to raise the carrying costs of housing and deter speculation. These include discontinuing crisis-related support for developers in the 2009 budget; disallowing interest-only loans; capping the loan-to-value ratio at 80 percent (down from 90 percent) in February; and introducing a seller's stamp duty on resale of properties within a year from purchase. In addition, reflecting the

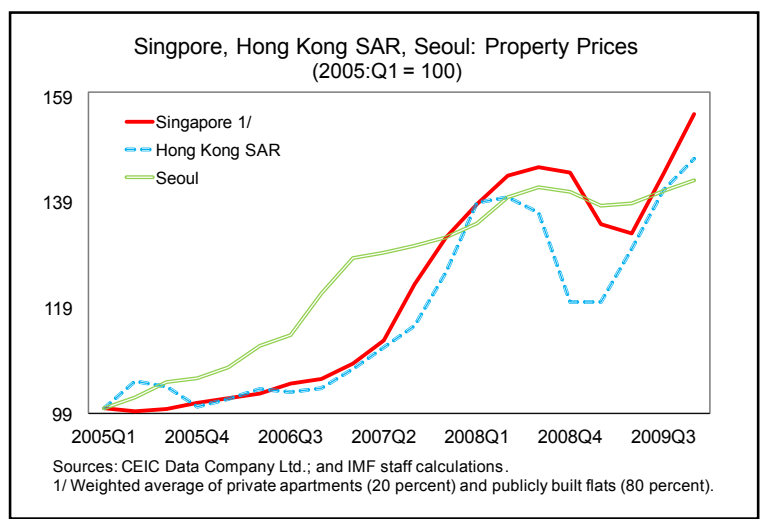
authorities' view that fundamental drivers linked to immigration and household formation are at play, in May the government released an unprecedented amount of land for residential housing. 
17. External drivers. The global environment improved faster than anticipated. Stronger external demand and more settled financial markets propelled Singapore's export-oriented activities with knock-on effects on private domestic demand. The process had an important regional dimension, with a key role played by the cross-border production networks centered on China as well as by the region's own end-demand. For example, China has become a high-growth market for Singapore's tourism services and the insurance industry.

18. Internal factors. On the domestic front, the authorities' response to the worsening conjuncture was forceful and comprehensive - a large fiscal stimulus, decisive monetary easing, and an array of measures to ensure financial stability and market functionality. In particular, employment subsidies and training programs were highly successful in supporting household confidence and businesses' bottom line. So were schemes to facilitate SME's access to credit. More generally, strong economic fundamentals and labor market flexibility (due in part to the widespread use of bonuses in wage setting) provided important buffers against the external shocks. Similar actions around the world amplified the effectiveness of domestic policies by lifting the limits of countercyclical intervention in a small and highly open economy.

\section{Policy Developments}

19. Context. With countercyclical support delivered and the recovery on firmer ground, macroeconomic management started to transition out of crisis-relief mode late last year. Policy normalization has by now been achieved, and the medium-term compass at the core of Singapore's policy frameworks is again center stage in economic decisions.

20. Monetary policy. In mid-April, the MAS - which targets a nominal effective exchange rate (NEER) band to safeguard price stability - tightened the policy stance by re-centering upward the policy band at the prevailing level of the NEER and returning to a "modest and gradual" appreciation of the NEER for the period ahead. The policy shift marked the end of the accommodative monetary conditions since October 2008. The move validated a stronger currency and implied a slight "revaluation" of the NEER.

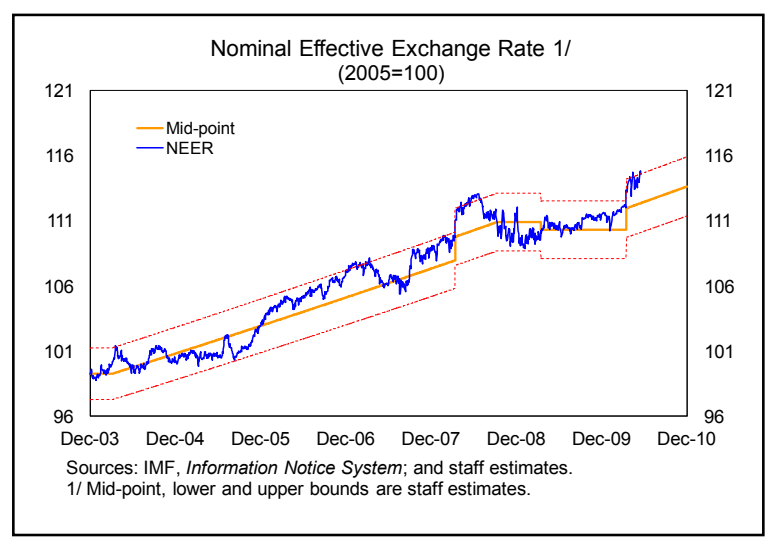

21. Fiscal policy. The 2009 budget, which envisaged an unprecedented countercyclical support, overperformed. The outturn benefitted from higher-than-anticipated tax revenues (from incomes and property) as well as some undershooting of expenditure. The deficit as defined by the authorities turned out at about 1 percent of GDP, some $2 \frac{1}{2}$ percent of GDP 
lower than planned. ${ }^{4}$ The 2010 budget (announced in February) envisages an unchanged deficit but some unwinding of fiscal countercyclical support. For example, the 2009 job subsidy scheme came to an end in June, and credit support to SMEs will be phased out by 2011 . Key initiatives in the 2010 budget underscore a return to a medium-term orientation for fiscal policy. In particular, the budget implements recommendations from the high-level Economic Strategies Committee (ESC) to foster productivity growth and reduce dependence on foreign labor through higher levies. ${ }^{5}$

22. Financial policies. The MAS ended some of the extraordinary support measures introduced during the crisis, including the currency swap agreement with the Fed. Other steps to exit from crisis-related measures are underway. In particular, the MAS has formed a working group with Bank Negara Malaysia and the Hong Kong Monetary Authority on exiting from blanket deposit guarantees by the end of 2010 - and raising the coverage of deposit insurance. Enhancements to the MAS liquidity facilities introduced during the crisis were intended all along to import best practices and have not been rolled back.

\section{OUTLOOK AND RISKS}

23. Near-term outlook. The economy is projected to expand nearly 10 percent in 2010. Both external and domestic demand should continue to support growth, although the exceptional momentum of the first quarter is bound to wane. Private consumption will benefit from further income gains while private investment will reflect post-crisis retooling and inventory accumulation. As temporary factors and policy support fade, 2011 GDP growth will be lower but still above potential. On this path, the output gap turns positive and inflation will be trending up, in part because of one-off factors. CPI inflation is projected at around $2^{1 / 2}$ percent this year. The authorities agree with the broad contour of these forecasts, noting that capacity expansion in a number of industries, including the opening of two large integrated resorts, should boost growth. The latest official projections are for GDP growth in the range of 7-9 percent and CPI inflation in the range of $2 \frac{1}{2}-3 \frac{1}{2}$ percent in 2010.

24. Risks. Concerns over fiscal sustainability in some euro area economies may undercut the global recovery or trigger market turbulence. Growth in Singapore would suffer if trade shrinks or credit dries up. Adverse spillovers through regional linkages could also arise from a large correction in China's property market —a tail risk. There may be upside surprises if

\footnotetext{
${ }^{4}$ The authorities' definition subtracts from the difference between revenue and operating expenditure top-up transfers to special funds (about 1 1/4 percent of GDP in 2010) and adds net investment income from fiscal reserves (about 3 percent of GDP).

${ }^{5}$ The ESC was established in March 2009 to develop growth strategies for Singapore in a changed world. It was chaired by the Minister of Finance and included representative from government, industry, and academia. Its recommendations are in $<$ www.esc.gov.sg $>$.
} 
the external environment improves more than anticipated, boosting export-oriented industries and financial activities. In this scenario, inflation risks will escalate.

25. Medium-term outlook. Medium-term economic prospects for Singapore hinge on the stamina of the global recovery and on structural shifts in advanced economies, as well as the impact of new productivity-enhancing reforms and lower reliance on foreign labor. In the baseline, GDP growth converges to a potential rate of about 4 percent, somewhat lower than average growth over the last decade.

26. Current account. The current account surplus as a share of GDP will remain sizeable over a five-year horizon-but not grossly out of line with the ratio probably consistent with Singapore's demographic structure, status as a financial center, and net foreign asset position, among other things. From a saving-investment perspective, private savings will feel the first impact of population aging and lower corporate profits as the economy adjusts. ${ }^{6}$ Private investment is projected to increase relative to GDP with planned expansions in the biomedical and chemical sectors.

More broadly, higher capital intensity

\begin{tabular}{|c|c|c|c|c|c|c|c|c|}
\hline \multicolumn{9}{|c|}{ Singapore: Ilustrabve Medium-Term Scenafio, 2007-15 } \\
\hline & \multicolumn{8}{|c|}{ Proj } \\
\hline & 20072008 & 2009 & 20102 & 20112 & 2012 & 20132 & 20142 & 2015 \\
\hline \multicolumn{9}{|l|}{ Resil grouth (percent change) } \\
\hline $\cos$ & $6.5+8$ & $-1,3$ & 9.9 & 4.9 & 45 & 4.4 & 43 & 40 \\
\hline Total domestic doosand & 7.847 & 4.9 & 9.0 & 5.7 & 5.7 & 5.5 & 54 & 4.9 \\
\hline Net experts $/ 4$ & $47-90$ & 23 & 3.4 & 0.5 & 01 & 0.1 & 01 & Q.1 \\
\hline \multicolumn{9}{|c|}{ Sowing and imestment (percent of GDP) } \\
\hline Gross national savings & 47948.5 & 450 & 46.4 & 451.201 .0 & 443 & 439. & 437. & 432 \\
\hline Geoss caphial lormation & 212299 & 272 & 27.8 & 27.3 & 27.3 & 28.22 & 20.62 & 29.2 \\
\hline Current accourt balance & 26.718 .5 & 17.8 & 186 & 17.4 & 16.5 & 15.7 & 152 & 140 \\
\hline \multicolumn{9}{|l|}{$\begin{array}{l}\text { Inflation and unemployment. } \\
\text { (poriod average, percent) }\end{array}$} \\
\hline CPI inflation & 2.165 & 0.6 & 2.5 & 2.1 & 2.1 & 2.1 & 21 & 20 \\
\hline Unemployment rate & $21 \quad 2.2$ & 30 & 2.2 & 2.3 & 2,3 & 2.3 & 21 & 21 \\
\hline \multicolumn{9}{|c|}{ Sourcas: staff estimates and projections } \\
\hline 1) Contribution to COP gom & & & & & & & & \\
\hline
\end{tabular}
is a likely outcome of recently launched reforms and incentives. Public investment will also remain strong, with a pipeline of projects in transport, health, and education. The authorities shared the staff views on the medium-term evolution of the current account. They also flagged the potential for reductions in public savings in the longer run, following last year's constitutional amendment that enables the government to use more of the returns on its reserves to fund the budget.

\section{Policy Discussions}

\section{A. Macroeconomic Policies on the Recovery Path}

27. Context. Monetary, fiscal, and macroprudential policies are appropriately aimed at sustaining the expansion and curbing risks in the goods and asset markets. However, the road ahead could be bumpy and flexibility in policymaking remains a priority.

\footnotetext{
${ }^{6}$ The old-age dependency ratio, currently at about 12 percent, is projected to increase to about 16 percent by 2015.
} 
28. Monetary policy. The MAS' latest two-step recalibration of the policy settings has restored a neutral stance. In light of projected output and price dynamics, this is appropriate. There was agreement that, barring a significant change of the outlook for growth or inflation, monetary policy should stay the course. The staff and the MAS shared the view that, if modest headwinds are encountered, the width of the NEER band provides a ready-made shock-absorber. However, if tail risks materialize - for example, if contagion from Europe spins out of control or capital flows undermine price stability — the policy adjustment will need to be bolder.

29. Capital inflows. Regarding risks posed by volatile capital movements, the MAS noted that gross inflows remain well below the 2006-07 peak and that traditionally Singapore has been a net exporter of capital. In fact, surges in capital inflows, such as that in the first quarter of 2010, are generally intermediated out of the country. In the authorities' view, there is little evidence that capital inflows are a significant source of asset price bubbles in Singapore. There was agreement that coping with extraordinary capital inflows could pose challenges under the MAS' policy framework, including the possibility that a faster appreciation of the exchange rate may attract further speculative activity. When necessary, the MAS has intervened in the foreign exchange market to dampen upward pressure on the Singapore dollar (and thus deliver price stability), sterilizing the liquidity injections to limit the volatility of domestic interest rates.

30. Bubble risks. The return to an appreciation path for the NEER has brought along a lower cost of credit for businesses and households, with a possible impact on asset prices. ${ }^{7}$ The authorities shared the view that there may be hot spots in the private housing market where prices have moved significantly faster than developments in the broader economy since it turned around in 2009. However, fundamentals too are at play and may explain much of the action. There was agreement that systemic risks are mitigated by several considerations: (i) the majority of mortgages have loan-to-value ratios below the regulatory ceiling; (ii) bank exposure to the property sector (excluding mortgages on owner-occupied houses) remains well within prudential norms; (iii) mortgage providers have been tightening for some time the terms of their loans; (iv) low unemployment suggests few household delinquencies in the pipeline; and, most importantly, (v) the bulk of the housing market (which is for publicly built apartments) shows little signs of froth. ${ }^{8}$ Tellingly, Singapore's

\footnotetext{
${ }^{7}$ With the NEER as the intermediate target of monetary policy and unfettered capital mobility, a monetary tightening (a faster trend appreciation of the NEER) implies a decline in nominal interest rates consistent with uncovered interest parity. The impact of the stronger currency more than offsets the stimulus from lower interest rates, leading to tighter monetary conditions. See IMF, Country Report No. 08/281 for an analysis of the monetary transmission mechanism in Singapore.

${ }^{8}$ Housing loan NPLs are currently about $1 / 2$ of 1 percent of total loan and the ratio of monthly mortgage payments to monthly income (an indicator of affordability) is less than 25 percent.
} 
private properties have undergone a major price correction in 2008-09 with no systemic ripple effects.

31. Fiscal policy. Like the stimulus of last year, the withdrawal of fiscal support has been timely and well calibrated. The bulk of the fiscal impulse has been taken away, notably with the rolling back of the Jobs Credit Scheme and the expiration of other extraordinary interventions in the 2009 budget. The fiscal stance is now about neutral and in tune with internal balance. With output close to trend, the 2010 budget rightly focuses on measures to strengthen potential growth.

\section{B. Policies in the Financial Sector}

32. Context. There was agreement that Singapore's financial sector is strong. Domestic banks are funded primarily through retail deposits. Their loan-to-deposit ratio is below 90 percent, regulatory capital is about 17 percent of risk-weighted assets (the Tier 1 ratio is 14 percent), and the liquid asset ratio is about 18 percent. All these indicators imply ample cushions over statutory requirements. At about 2 percent of total loans, NPLs at local banks are only marginally up. Foreign banks (which account for over half of banking assets) are subject to strict licensing procedures and the MAS has an ongoing dialog with both head offices and home-country supervisors of the larger institutions. Insurers have seen investment income and new business premiums recover. They continue to have strong capital and liquidity buffers as well as a conservative asset mix. Hedge funds, wealth management, private banking, corporate fund advisory, and REITs are another important segment of Singapore's financial system. Under redemption pressures, assets under management dropped to about $\mathrm{S} \$ 860$ billion at end-2008 from over $\mathrm{S} \$ 1$ trillion a year earlier. A recovery has been underway since, and the fund management industry is expected to keep expanding although not as fast as pre-crisis.

33. Banks. The latest round of stress tests based on severe assumptions about international and domestic shocks suggests that, even in worst-case scenarios, NPL ratios at local banks would remain below historical highs and capital adequacy would not be impaired. Direct exposures to banks in fiscally-stressed European countries are small. ${ }^{9}$

34. Insurance. The MAS has strengthened the insurers' stress testing framework by introducing stress-to-failure scenarios. It has also been reviewing Singapore's policy owner's protection scheme with a view to broadening coverage and providing for pre-funding.

\footnotetext{
${ }^{9}$ For example, the MAS estimates that the exposure of Singapore-incorporated banks to the troubled European economies amounts to less than 1 percent of their assets. Assuming the same rate of withdrawal as during the global financial crisis, any decline in Europe-sourced deposits is not expected to exceed 5 percent of total deposits as of Mar 2010.
} 
35. OTC-traded derivatives. The Singapore Exchange has proposed to set up a facility to provide for central counterparty clearing of certain financial derivative contracts traded overthe-counter (interest rate swaps and Asian foreign exchange forward contracts settled in U.S. dollars).

36. Asset management. The MAS has proposed a licensing regime for fund management companies (including hedge funds) that manage assets in excess of S\$250 million. Capital requirements and fit-and-proper tests for managers and staff would also apply. These changes are unlikely to shake up the industry. In the MAS' view, there are no clear signs yet that stricter regulations in Europe and the United States are creating incentives for hedge funds to relocate to Singapore or other jurisdictions in Asia.

37. Deposit insurance. As part of its regular review, the MAS has proposed enhancements to the deposit insurance scheme including raising the deposit insurance coverage limit. Ninety percent of depositors would be insured once the ceiling of deposit protection is more than doubled, as proposed by the MAS. Staff noted that, in this connection, consideration could be given to the adoption of risk-based premia.

38. Corporate governance. Finally, in March, the MAS proposed several enhancements to current guidelines on corporate governance. These enhancements (relating for example, to the composition of the Board and structures for risk management) would apply to banks incorporated in Singapore and certain finance and insurance companies.

\section{Post-Crisis Issues}

39. Context. Among the many global issues brought to the fore by the financial crisis, four are particularly relevant from Singapore's perspective: Basel III, self-insurance through official reserves, the design of social safety nets, and strategies to increase productivity. The first issue speaks to Singapore as a financial hub; the second resonates with Singapore's persistent current account surpluses; and the last two are related to the ESC's goals to make economic growth more inclusive and improve medium-term prospects.

40. Basel III. There was broad agreement that the impact of tighter prudential requirements on capital, liquidity, and leverage is not expected to be too onerous for Singaporean banks, which are already well capitalized, have stable funding sources, and whose risky assets are well reserved. Raising the quality of capital may be the greatest challenge, but it should be manageable. The situation is less clear for foreign banks and nonbanks. The impact of other reforms under discussion (e.g., levies, surcharges on systemically important financial institutions, counter-cyclical capital buffers) remains more speculative, given lack of specificity so far on the design of the reform package. A final assessment will have to wait for greater clarity about the calibrations, which will determine if foreign banks will expand or contract activities in Singapore. Much will also depend on developing closer cooperation among supervisors in different jurisdictions. The MAS emphasized that - as an international consensus is forged to make the global financial system 
safer-some discretion in implementation should in any case be left to national authorities who can best assess local conditions.

41. Official reserve buffers. In the authorities' view, Singapore's accumulation of foreign assets reflects transitional dynamics. They note that a combination of factors specific to Singapore - very small size, lack of natural resources, financial center status, large presence of multinationals, and population aging - calls for high savings (including by corporates) and a large desired stock of net foreign assets (NFAs) as a buffer against volatility and as a diversified store of wealth. Indeed, strong external and fiscal positions have been key to shielding Singapore's financial sector from the turbulence that has crippled other economies with large banking systems - a point recognized in a recent IMF Board paper. This said, the underlying stock adjustment is bound to come to an end in the foreseeable future. The first baby boomers will begin to retire two years from now and public spending is likely to increase over the medium term and beyond. Both developments - the authorities arguedwill mark a shift in saving behavior and a move toward stabilizing the NFA ratio.

42. Social safety nets. Fund recommendations in previous Article IV consultations to strengthen Singapore's social safety nets have not found much traction. Discussions this time provided a clearer context. According to the authorities, Singapore has an extensive system of social programs that protects the least advantaged without undermining self-reliance. Through "invisible but real" social safety nets, government assistance builds on personal and local community support, fostering both family cohesion and social harmony. ${ }^{10}$ They also note that, unlike those in many advanced economies, Singapore's social security system does not create a burden for future generations - and its effectiveness may be poorly captured by OECD-type indicators that mask intergenerational inequities or the role of policies to promote alternative saving vehicles, in particular home ownership. ${ }^{11}$ This said, the authorities acknowledge that there remains the challenge of adapting existing programs to fast-changing economic and social circumstances - and sharpen the means to give lower-income Singaporeans the skills they need for a better future. Taking note of this position, staff still argued that generational accounting calculations suggest very large transfers from the current to future generations and that there is scope for further developing mechanisms to make housing wealth more liquid or increase the return on pension contributions.

43. Productivity growth. The staff and the authorities shared the view that faster productivity gains hold the key to keeping Singapore on the cusp of economic success (Box 3). In fact, the ESC has set the goal of doubling labor productivity growth to about

\footnotetext{
${ }^{10}$ For example, Singaporeans can approach the Community Development Councils—which have access to government funds - to help address their financial and medical needs.

${ }^{11}$ Indicators such as pension wealth, coverage, or replacement rates as calculated in the OECD Pensions at a Glance: Asia/Pacific Edition 2009 would suggest that Singapore's system of social protection is less generous than in comparable OECD members.
} 


\section{Box 3. Productivity Trends in Singapore}

Over time, Singapore's economy has branched out into high value-added sectors (pharmaceuticals, biomedical, and aeronautical engineering) and financial services.

Despite these developments, real GDP growth slowed significantly in the last decade compared to the 1980 s and 1990 s.

\section{A decomposition of growth into the contributions of labor, capital, and total factor} productivity (TFP) casts some light on the underlying reasons. The contribution of TFP has declined steadily from over 20 percent in the 1980s to around 14 percent in the 2000s (implying an average growth rate of approximately $3 / 4$ of 1 percent in the last decade). The contribution of capital has also fallen, from about two-thirds of GDP growth in the 1980s to just under one-half in the 2000s. At the same time, labor has become a more important input in production: its

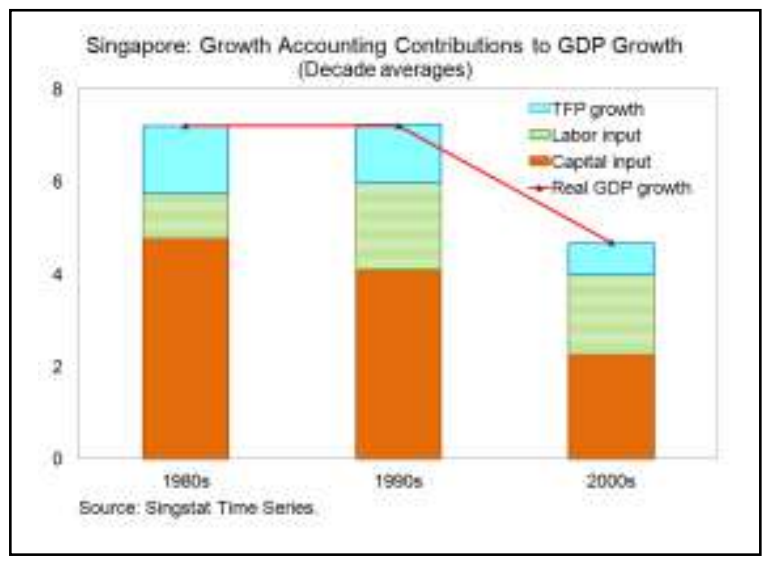
contribution tripled to nearly 35 percent of GDP growth in the 2000s.

The TFP slowdown is a concern. If the contributions from capital and TFP continue to decline in the years ahead, Singapore's ability to sustain steady gains in labor productivity and wages could be at risk. Indeed, trend growth in labor productivity began to slow even prior to the crisis. $^{1 /}$

\section{The government has recognized the need to} raise productivity across the board. The Economic Strategies Committee has called for a comprehensive program to double economy-wide productivity growth over the next ten years. To this end, it recommends a focus on training, promoting research and

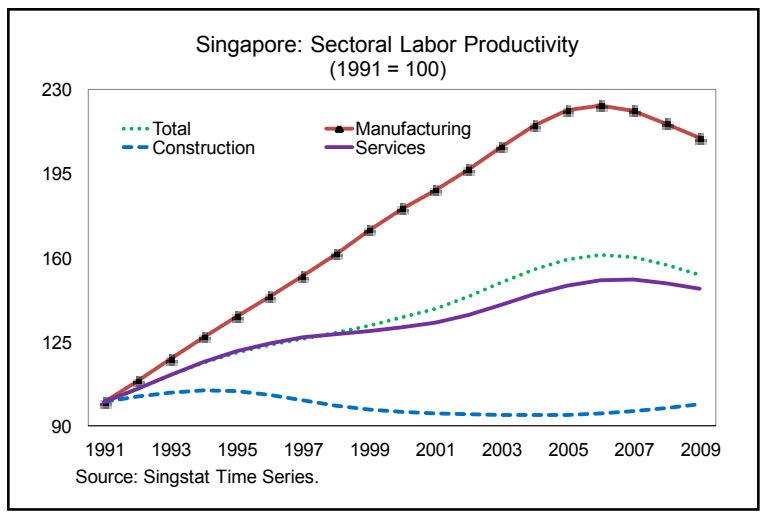
development activities, and boosting the attractiveness of Singapore as a hub for high-value added activities.

1/ Annual data on labor productivity are detrended using the Hodrick-Prescott filter with smoothing parameter set at 6.25 . 
$2^{1 / 2}$ percent per year over the next ten years. The measures in the budget to encourage capital deepening, upgrade worker skills, and enhance innovation are significant steps toward expanding Singapore's technology frontier, although they will take time to pay dividend. ${ }^{12}$ The authorities noted that, in addition to lifting wages of Singaporeans at the low end of the distribution, the planned gradual increase in foreign worker levies would also contribute to boost labor productivity by strengthening other supply-side incentives to re-optimize the capital-labor mix.

\section{Exchange Rate Assessment}

44. Developments. For most of 2009, the Singapore dollar in real effective terms (REER) has moved side-ways. However, it has strengthened somewhat following the resumption in April of a targeted trend appreciation of the NEER. The current account was about 18 percent of GDP in 2009, only marginally lower than a year earlier. Over the medium term, it is projected to decrease modestly at an (approximately) unchanged REER (see paragraph 26).

45. Assessment. The authorities and the staff agreed that the Singapore dollar REER will strengthen over the medium term as the domestic economy continues to expand and ongoing shifts in the pattern of production and global demand play out. This said, staff estimates that the real effective value of the Singapore dollar is somewhat weaker than its equilibrium (Box 4). This assessment is subject to considerable uncertainty surrounding, among other things, the projected current account surplus five years from now- a critical ingredient in the methodologies used. The staff noted that from a multilateral perspective, a shift of the policy mix to a tighter monetary policy and a more expansionary fiscal policy would reduce the current account surplus while safeguarding internal balance. With such a shift, the REER undervaluation could be eliminated over the medium term without prejudice to domestic stability. The authorities were once again skeptical about this assessment. In their view, CGER-like methodologies do not do justice to key features of the Singaporean economy (see paragraph 41), and are opaque as to the policy implications. According to the MAS' valuation models, the real effective Singapore dollar is broadly in line with its fair value. There was agreement that Singapore's exchange rate regime continues to serve the country well.

\footnotetext{
${ }^{12}$ Initiatives include tax deductions and technical assistance to increase business efficiency, programs to improve SME's access to finance and nurture start ups, as well as educational and training support for Singaporeans.
} 


\section{Box 4. Singapore: Exchange Rate Assessment}

The real effective Singapore dollar is somewhat weaker than its estimated medium-term equilibrium level.

After appreciating between 2005-mid 2008, the real exchange rate has been stable until April 2010. The recent uptick comes in the wake of the MAS's decision to target a "modest and gradual" appreciation for the currency in nominal effective terms, going forward.

To assess the level of the exchange rate in relation to its medium-term equilibrium, three methodologies have been used: $1 /$

- The macroeconomic balance approach estimates a current account

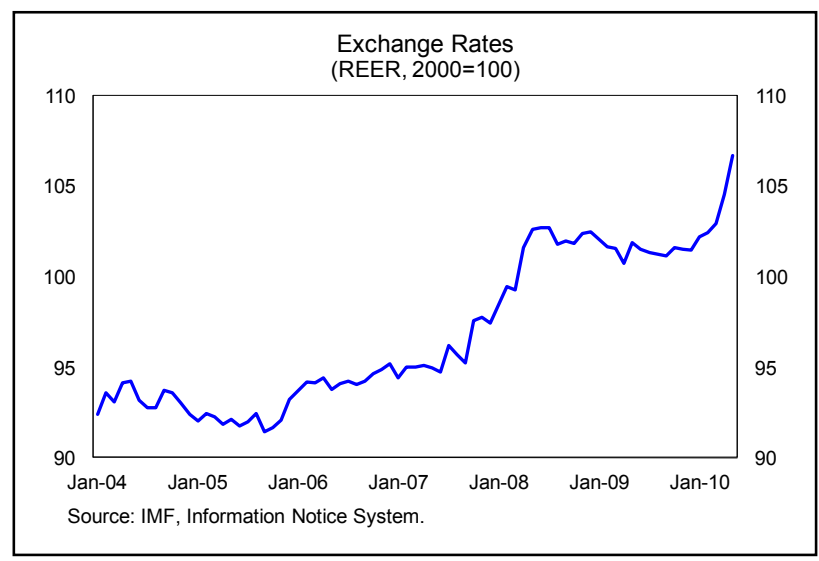
"norm" of about 11 percent of GDP. Estimates of the norm are derived from a panel of 55 advanced and emerging economies. According to the macroeconomic balance approach, the Singapore dollar is undervalued by about 8 percent (after adjusting for multilateral consistency).

- The external sustainability approach also points to an undervaluation but the extent depends on the level of net foreign assets (NFA) assumed as a benchmark. Under the assumption that the net foreign asset position (NFA) is stabilized at its 2009 level (estimated at about 142 percent of GDP), the implied undervaluation is about 16 percent. This assumed level of NFA is much lower than that at the time of the 2009 Article IV report (175 percent of GDP), reflecting imputed capital losses during the global financial crisis, and is known to be an underestimate. Computing, instead, Singapore's NFA position with cumulative current account balances gives an NFA estimate of around 200 percent of GDP — and an undervaluation of the Singapore dollar in real effective terms of around 7 percent.

- The equilibrium exchange rate approach suggests that the exchange rate is broadly in line with medium-term fundamentals. According to this approach, the exchange rate is about 1 percent below its equilibrium.

1/ These are the methodologies developed by the IMF's Consultative Group on Exchange Rate Issues. See Exchange Rate Assessments: CGER Methodologies, IMF Occasional Paper No. 261, 2008. 


\section{StAFF APPRAISAL}

46. Crisis impact. Thanks to Singapore's strong fundamentals and policy frameworks, the global downturn of 2008 took a smaller toll on the domestic economy than initially feared. The authorities should be commended for a decisive and timely countercyclical support that dulled the impact of collapsing trade and market sentiment.

47. Macroeconomic setting. Buoyed by improved external and domestic demand, Singapore's economy is now on a broad-based recovery path. Output losses have been recouped and policies have shifted their focus from crisis relief to sustaining the expansion. In view of lingering fragilities in the world economy, flexibility in policymaking remains a priority. As shown during the global recession, Singapore has a strong track record of proactive and forward-looking economic policymaking.

48. Monetary policy. The Monetary Authority of Singapore's (MAS) latest recalibration of policy settings has unwound earlier monetary stimulus and restored broadly neutral monetary conditions. In light of projected output and price dynamics, this is appropriate. An appreciation bias for the Singapore dollar in effective terms is consistent with internal and external stability. Barring a significant change in the outlook for growth or inflation, monetary policy should stay the course.

49. Capital inflows. Managing disruptive capital flows is not an immediate challenge for the MAS. Nonetheless, unsettled global financial markets and the expectation of changes in key regional currencies points to heightened volatility in international capital movements into and out of Singapore, going forward. Under the MAS policy framework, this volatility could undermine the stability of goods and asset markets and will need to be addressed, as the MAS has done all along, through carefully calibrated exchange rate policies and macroprudential tools.

50. Fiscal policy. The exit from crisis-related support has largely been completed and fiscal policy has regained its traditional medium-term orientation. The fiscal settings are now close to neutral and in tune with internal balance. Multilateral considerations suggest the desirability of a secular shift of the policy mix toward a more expansionary fiscal stance. From this perspective too, the authorities' intention to increase spending in physical and social infrastructure over the medium term is welcome.

51. Financial sector policies. Singapore's financial sector emerged largely unscathed from the global financial crisis, thanks to strong supervision and risk management systems. Plans (in coordination with other regional jurisdictions) to unwind by year-end the blanket deposit guarantee and move to a system with higher deposit coverage are commendable, as they ensure international consistency among economies with strong financial linkages. As part of these changes, consideration could be given to making deposit insurance premia riskbased to ensure risk management discipline in financial institutions. 
52. Property market boom. The exuberance in some segments of the property market does not seem to be of systemic importance. Sales of public land and macroprudential measures so far have been part of a contingent, preemptive, and graduated strategy to curb excesses. The authorities should continue to monitor the situation closely and build on the measures already taken, if necessary.

53. Basel III. Revamped regulations on capital, liquidity, and leverage should not be too onerous for local banks, which are already well capitalized and whose risky assets are well reserved. Focus on sound supervision will continue to serve Singapore well. Since the financial crisis, the MAS has undertaken several public consultations on new rules to enhance regulatory standards. Proposals aiming at strengthening investor protection and increasing the responsibility of senior management at financial institutions indicate that the MAS does not shy away from a prescriptive approach to regulations where needed.

54. Official reserve accumulation. Building strong reserve buffers has been a central plank in Singapore's economic strategy, given its small economic size, lack of natural resources, demographics, and status as a financial center. While this is an understandable social choice, the authorities are encouraged to keep it under review, lest a generationally inequitable outcome or an inefficient allocation of resources results.

55. Social safety nets. Singapore's societal preferences are also reflected in its approach to social insurance whereby "real but invisible" social safety nets mitigate hardship without undermining work incentives. As the system is adapted to a changing economic and social landscape, consideration could be given to more orthodox enhancements such as ways to raise the return to pensioners and facilitate the monetization of housing wealth.

56. Exchange rate. The REER is somewhat weaker than its medium-term equilibrium. This assessment — which is subject to considerable uncertainty — suggests a likely strengthening of the currency over time. Singapore's exchange rate regime continues to serve the economy well and the MAS' exchange-rate-centered monetary framework has been an important source of stability in times of economic turbulence.

57. It is recommended that the next Article IV consultation discussions take place on the standard 12-month cycle. 
Figure 1. Singapore: Real Sector Developments

GDP growth recovered in the second half of 2009.

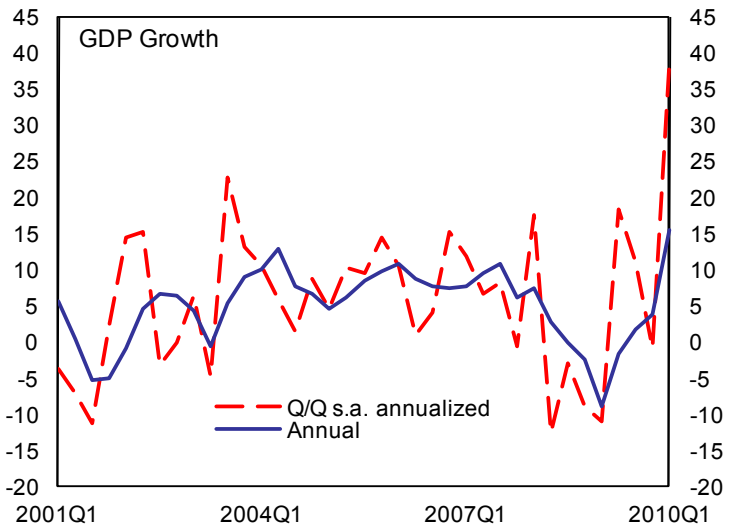

Manufacturing started to recover in the second half of $2009 .$.

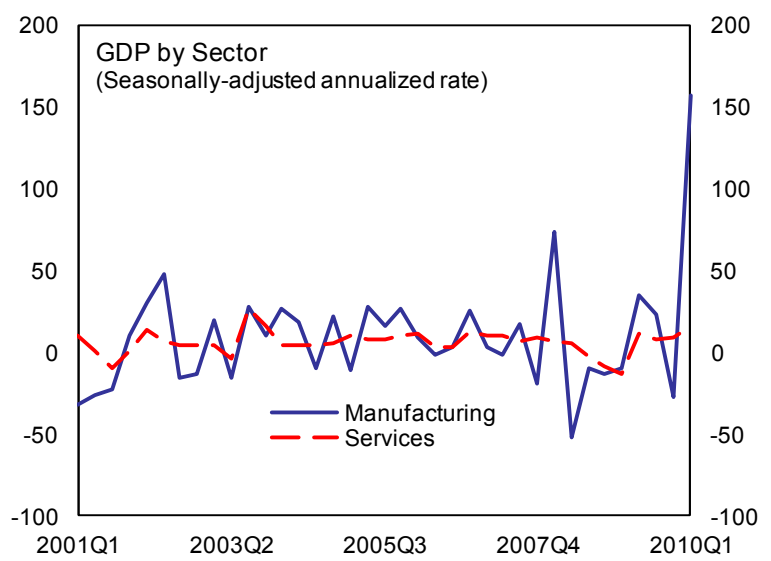

Labor markets have improved.

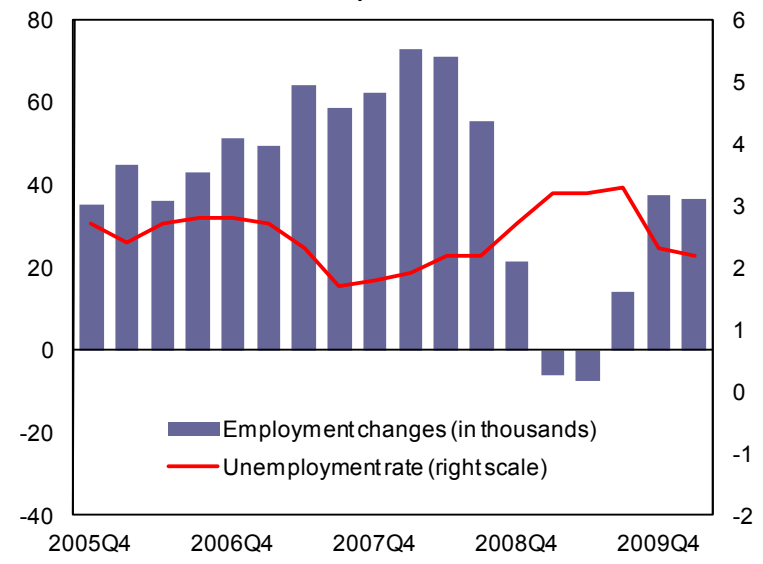

Net exports propelled the upswing, which has become more broad based.

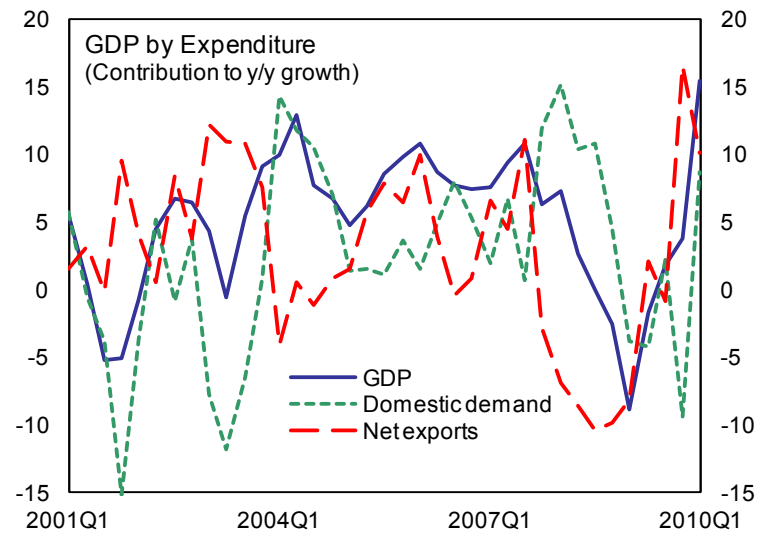

...especially electronics.

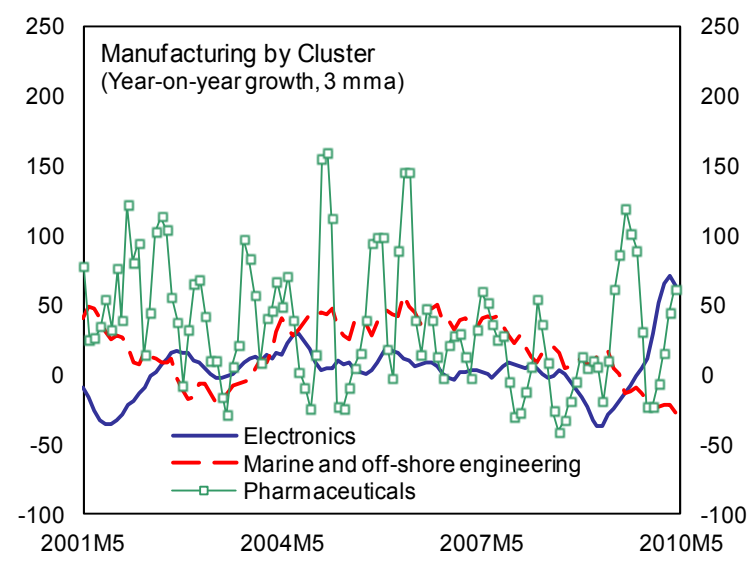

Inflation is picking up, but remains low.

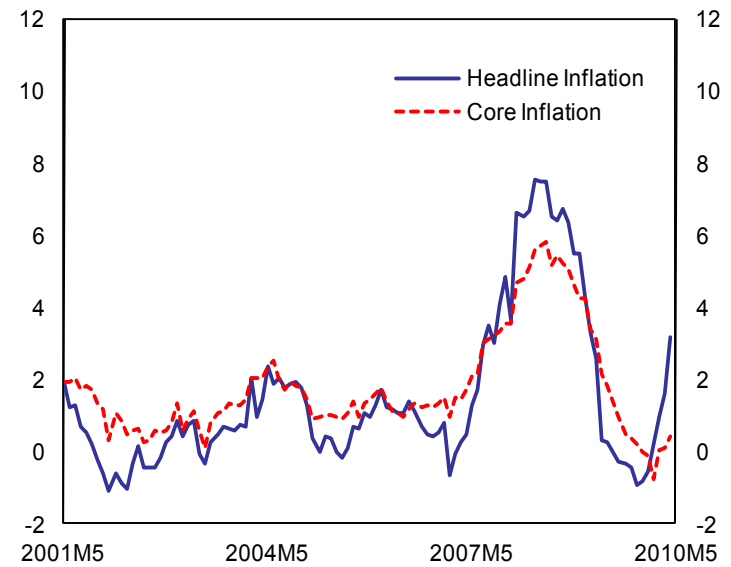

Source: CEIC Data Co. Ltd; and IMF staff estimates. 
Figure 2. Singapore: Asset Market Developments

Interbank interest rates have been stable at low levels...

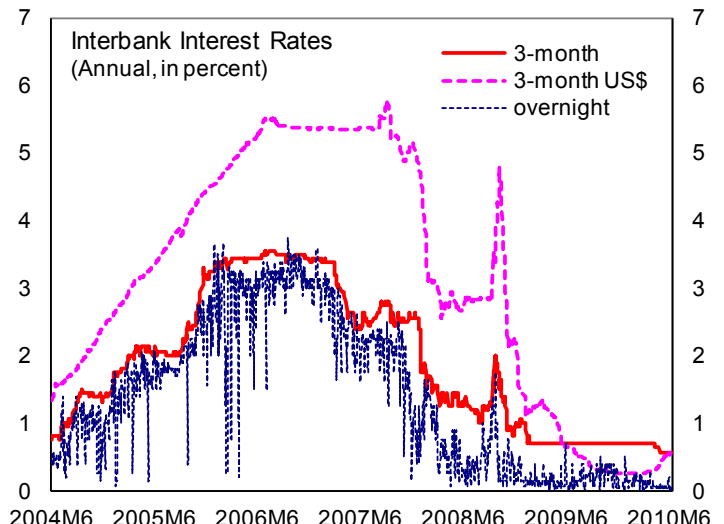

The equity market rallied in early 2009

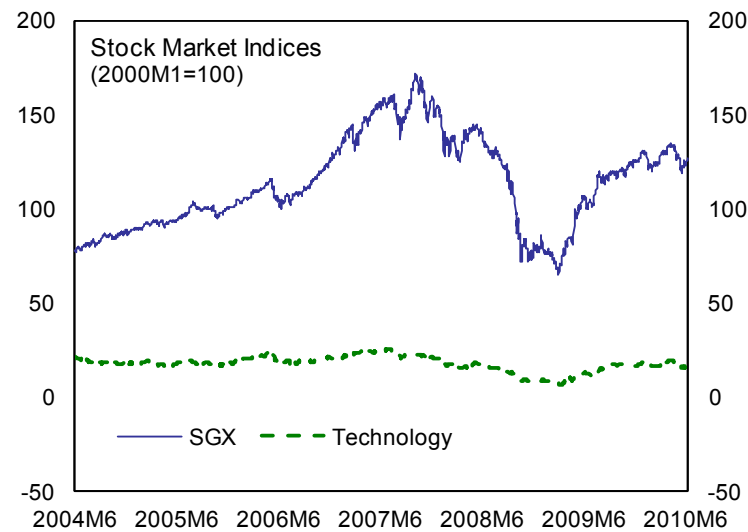

Residential property markets rebounded...

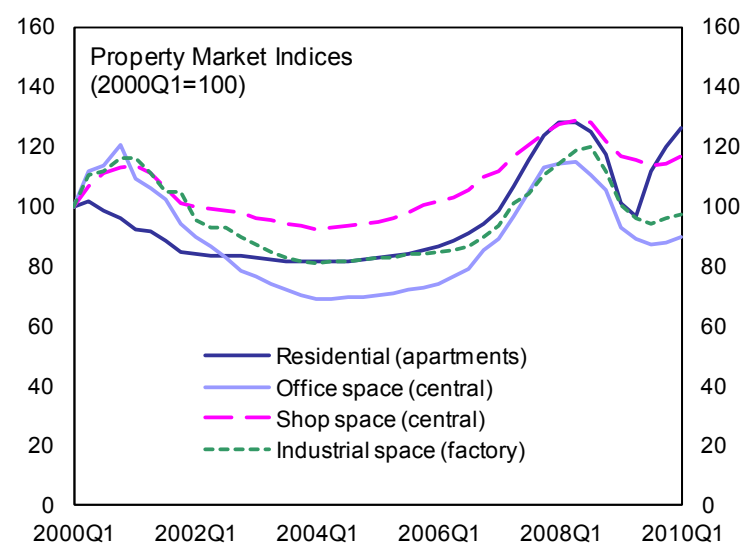

...and FX volatility has been moderate.

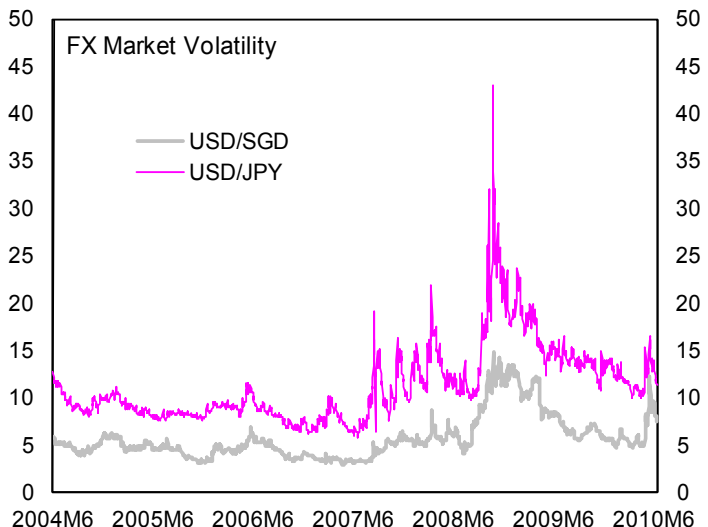

...as elsewhere in the region.

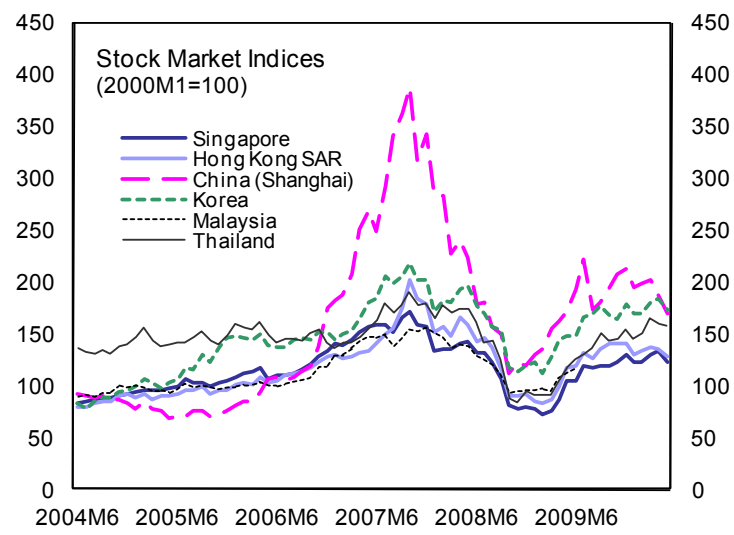

...but do not seem to be out of line with other countries in the region.

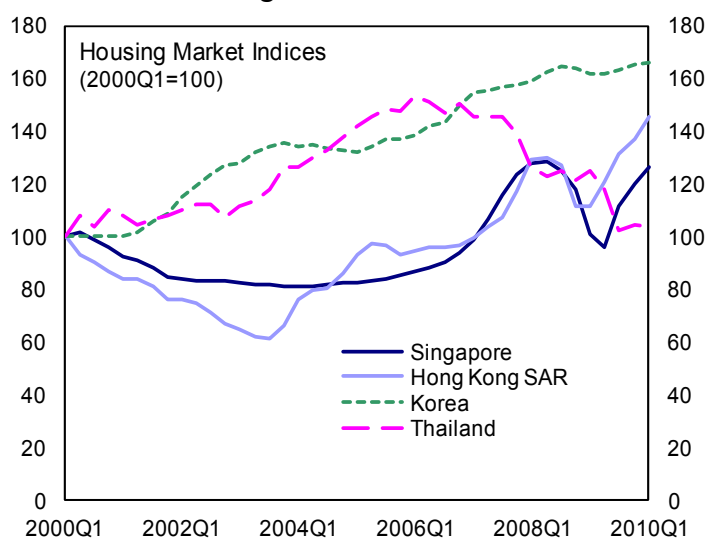

Sources: CEIC Data Co. Ltd.; Bloomberg L.P.; and IMF staff estimates. 
Figure 3. Singapore: External Developments

Exports rebounded...

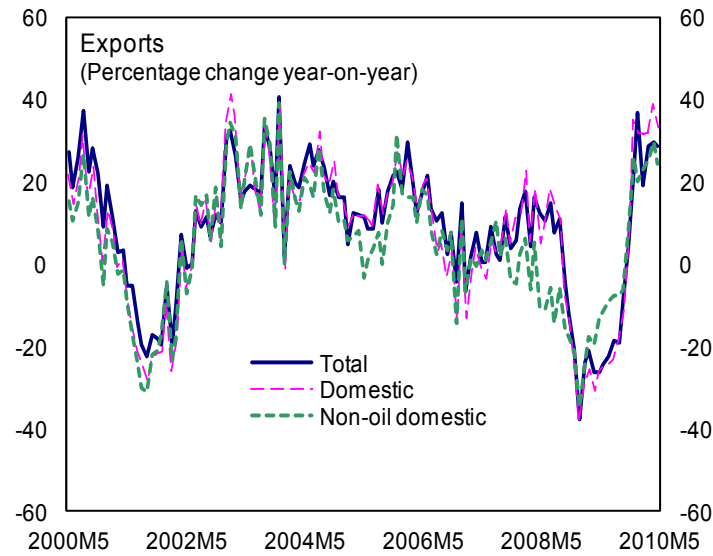

The current account surplus remains

significantly lower than pre-crisis levels....

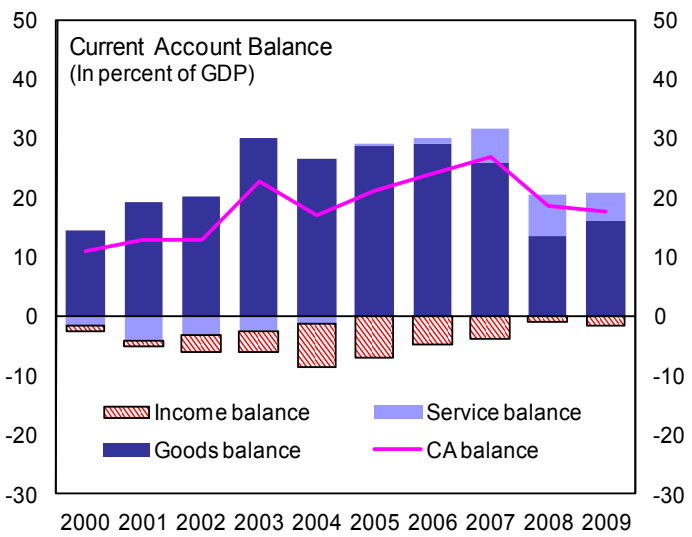

The financial account turned positive...

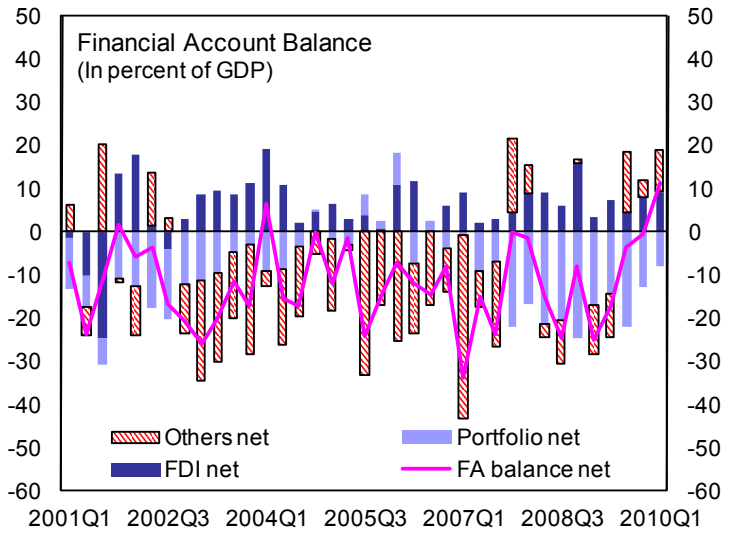

...as have imports.

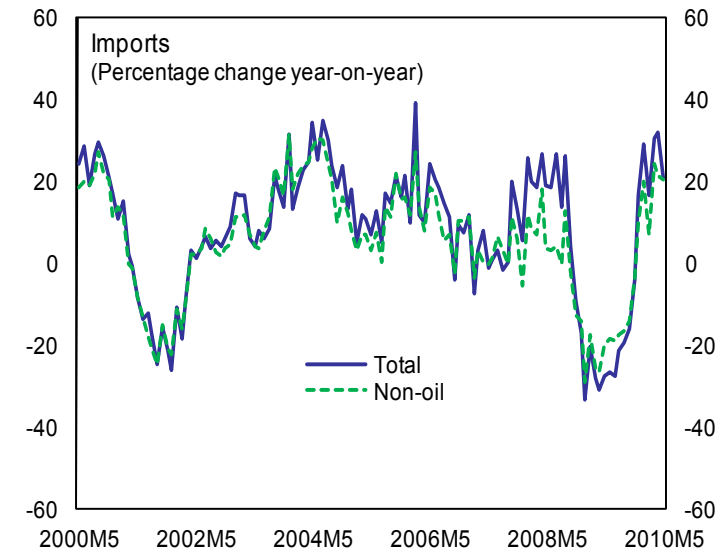

....and the real effective exchange rate started appreciating.

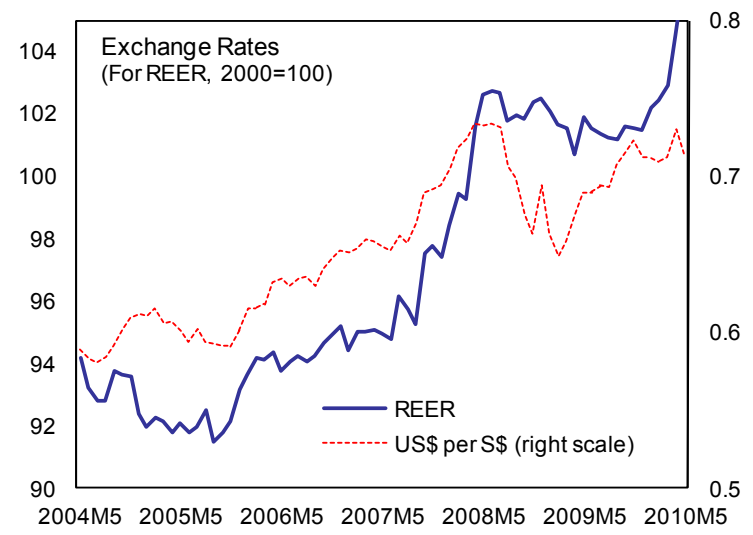

....and gross reserves started to increase.

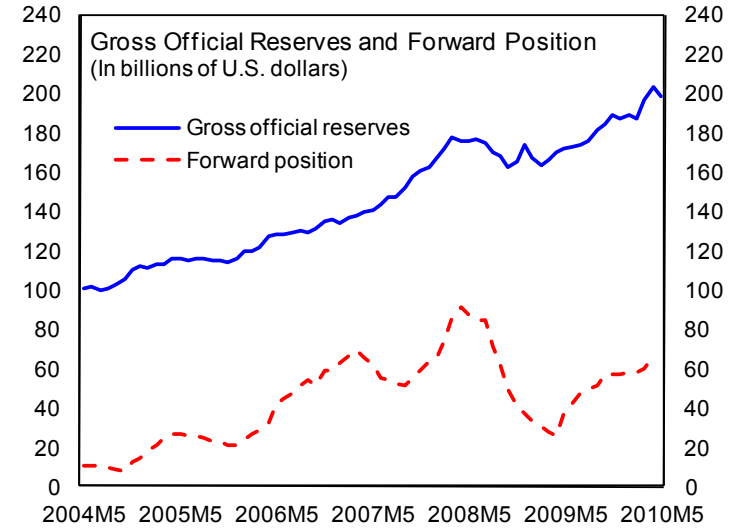

Source: CEIC Data Co. Ltd.; Singapore, Department of Statistics; and IMF staff estimates. 
Figure 4. Singapore: Financial Sector Developments

Capital adequacy is ample...

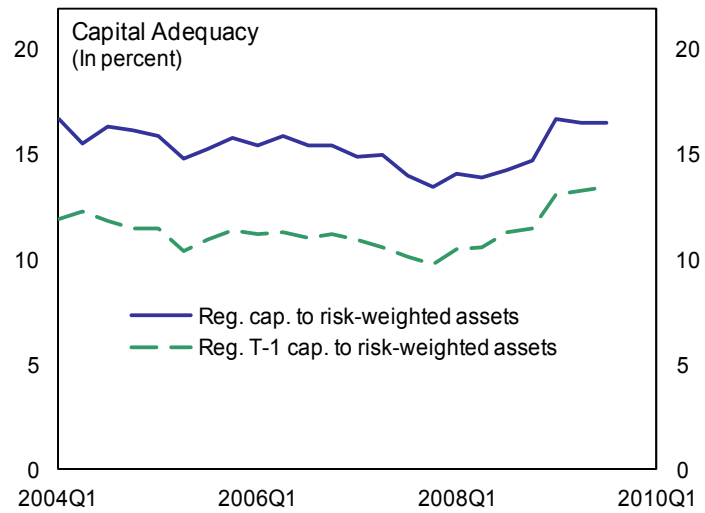

Banks' profitability has remained stable...

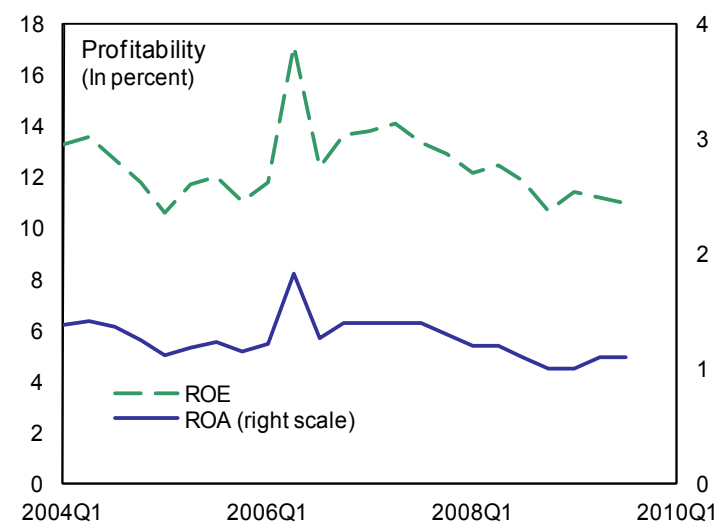

The corporate sector remains healthy...

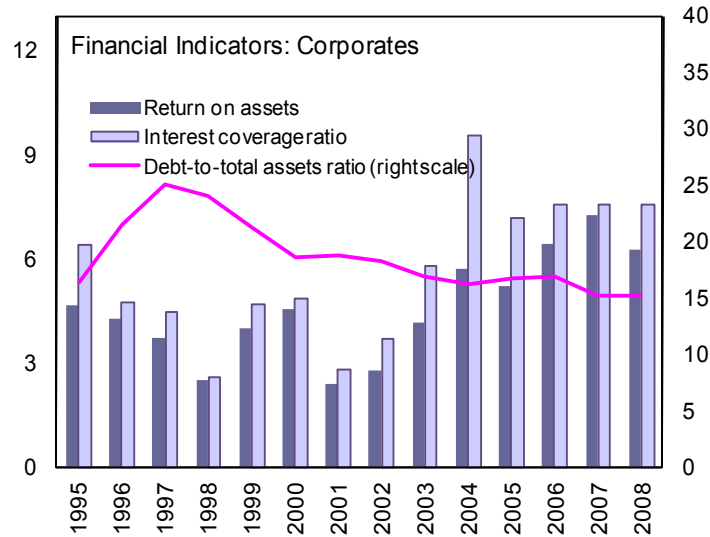

....and the NPL ratios are edging down.

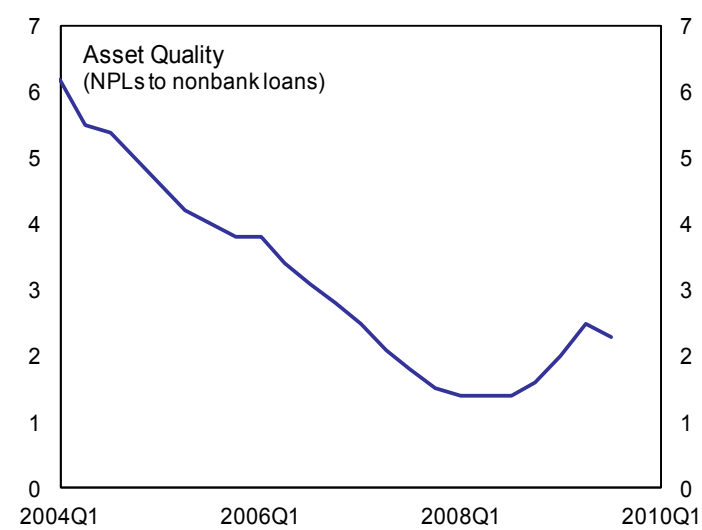

...and lending activity is expanding.

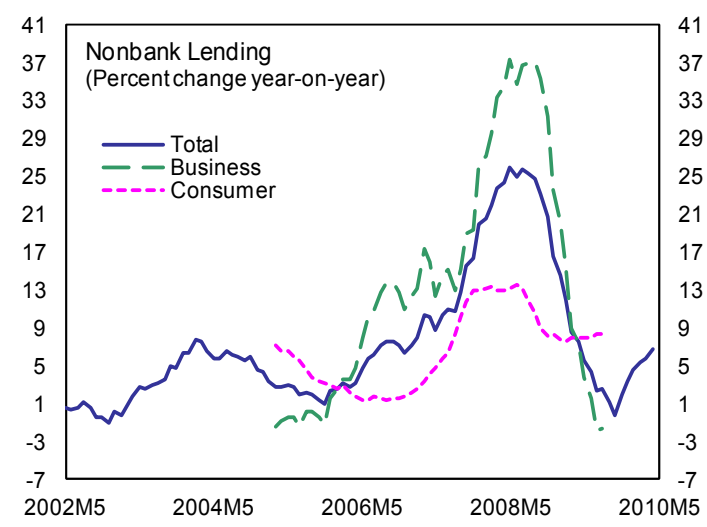

...and household balance sheets continue to be strong.

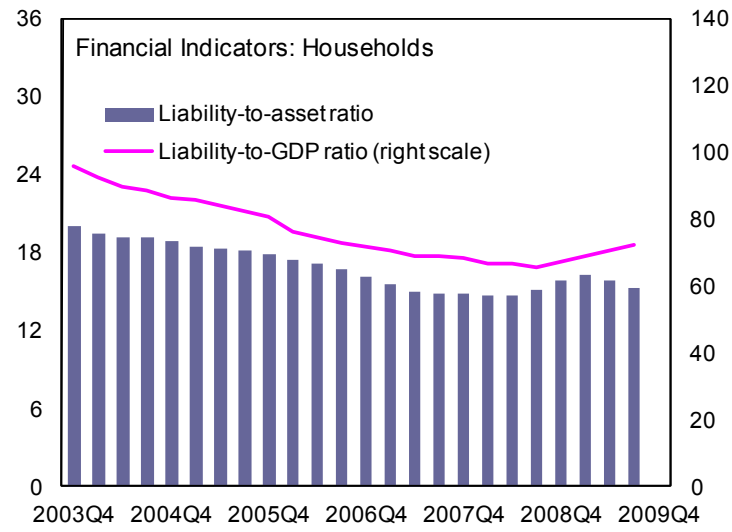

Sources: CEIC Data Co. Ltd.; the Monetary Authority of Singapore; and IMF staff estimates. 
Table 1. Singapore: Selected Economic and Financial Indicators, 2005-11

Nominal GDP (2009): US\$182.2 billion

Main exports (percent of total domestic exports): Electronic products (26\%); chemical products (18\%)

GDP per capita (2009): US\$36,537

Population (2009): 5.0 million

Unemployment rate (2009): 3.0 percent

\begin{tabular}{|c|c|c|c|c|c|c|c|}
\hline & \multirow[b]{2}{*}{2005} & \multirow[b]{2}{*}{2006} & \multirow[b]{2}{*}{2007} & \multirow[b]{2}{*}{2008} & \multirow[b]{2}{*}{2009} & \multicolumn{2}{|c|}{ Proj. } \\
\hline & & & & & & 2010 & 2011 \\
\hline \multicolumn{8}{|l|}{ Growth (percentage change) } \\
\hline Real GDP & 7.4 & 8.6 & 8.5 & 1.8 & -1.3 & 9.9 & 4.9 \\
\hline Total domestic demand & 2.6 & 7.1 & 7.8 & 14.7 & -4.9 & 9.0 & 5.7 \\
\hline Consumption & 3.9 & 4.0 & 5.7 & 3.9 & 2.1 & 6.5 & 6.1 \\
\hline Private consumption & 3.6 & 3.1 & 6.5 & 2.7 & 0.4 & 5.8 & 6.0 \\
\hline Gross capital formation & -0.4 & 15.1 & 12.4 & 38.0 & -16.1 & 12.3 & 5.1 \\
\hline \multicolumn{8}{|l|}{ Saving and investment (percent of GDP) } \\
\hline Gross national saving & 41.3 & 45.0 & 47.9 & 48.5 & 45.0 & 46.4 & 45.1 \\
\hline Gross domestic investment & 20.0 & 20.8 & 21.2 & 29.9 & 27.2 & 27.8 & 27.7 \\
\hline \multicolumn{8}{|c|}{ Inflation and unemployment (period average, percent) } \\
\hline CPI inflation & 0.5 & 1.0 & 2.1 & 6.6 & 0.6 & 2.5 & 2.1 \\
\hline Unemployment rate & 3.1 & 2.7 & 2.1 & 2.2 & 3.0 & 2.2 & 2.3 \\
\hline \multicolumn{8}{|c|}{ Central government budget (percent of GDP) $1 /$} \\
\hline Revenue & 20.0 & 20.2 & 23.1 & 24.1 & 20.1 & 20.3 & 21.0 \\
\hline Expenditure & 12.8 & 13.0 & 12.6 & 17.0 & 20.2 & 20.5 & 20.8 \\
\hline Overall balance & 7.3 & 7.1 & 10.5 & 7.1 & -0.1 & -0.2 & 0.2 \\
\hline Primary operating balance & -1.3 & -1.4 & 0.3 & -1.9 & -4.9 & -4.2 & -4.3 \\
\hline \multicolumn{8}{|c|}{ Money and credit (end of period, percentage change) } \\
\hline Broad money (M3) & 6.4 & 19.1 & 14.1 & 11.6 & 10.6 & $\ldots$ & $\ldots$ \\
\hline Lending to nonbanking sector & 2.2 & 6.3 & 19.9 & 16.6 & 3.4 & $\ldots$ & $\ldots$ \\
\hline Three-month interbank rate( percent) & 3.3 & 3.4 & 2.4 & 1.0 & 0.7 & $\ldots$ & $\ldots$ \\
\hline \multicolumn{8}{|l|}{ Balance of payments (US\$ billions) } \\
\hline Current account balance & 26.7 & 35.1 & 47.2 & 35.8 & 32.4 & 40.7 & 40.8 \\
\hline (In percent of GDP) & $(21.3)$ & $(24.2)$ & $(26.7)$ & $(18.5)$ & $(17.8)$ & $(18.6)$ & $(17.4)$ \\
\hline Trade balance & 36.4 & 42.6 & 46.1 & 26.5 & 30.0 & 41.7 & 51.5 \\
\hline Exports, f.o.b. & 232.7 & 274.7 & 302.5 & 341.7 & 272.4 & 347.9 & 385.6 \\
\hline Imports, f.o.b. & -196.3 & -232.2 & -256.4 & -315.2 & -242.4 & -306.2 & -334.1 \\
\hline Financial account balance & -16.7 & -14.8 & -31.3 & -24.0 & -20.3 & -29.2 & -33.0 \\
\hline Overall balance & 12.3 & 17.0 & 19.4 & 13.1 & 11.3 & 11.1 & 7.4 \\
\hline $\begin{array}{l}\text { Gross official reserves (US } \$ \text { billion) } \\
\text { (months of imports) 2/ }\end{array}$ & $\begin{array}{r}116.2 \\
(4.7)\end{array}$ & $\begin{array}{r}136.3 \\
(4.9)\end{array}$ & $\begin{array}{r}163.0 \\
(4.9)\end{array}$ & $\begin{array}{r}174.2 \\
(6.4)\end{array}$ & $\begin{array}{r}187.8 \\
(5.7)\end{array}$ & $\begin{array}{r}198.9 \\
(5.6)\end{array}$ & $\begin{array}{r}206.3 \\
(5.4)\end{array}$ \\
\hline
\end{tabular}

Sources: Data provided by the Singapore authorities; and Fund staff estimates and projections.

1/ On a calendar year basis.

2/ In months of following year's imports of goods and services. 
Table 2. Singapore: Balance of Payments, 2004-11 1/

(In billions of U.S. dollars)

\begin{tabular}{|c|c|c|c|c|c|c|c|c|}
\hline & \multirow[b]{2}{*}{2004} & \multirow[b]{2}{*}{2005} & \multirow[b]{2}{*}{2006} & \multirow[b]{2}{*}{2007} & \multirow[b]{2}{*}{2008} & \multirow[b]{2}{*}{2009} & \multicolumn{2}{|c|}{ Proj. } \\
\hline & & & & & & & 2010 & 2011 \\
\hline Current account balance & 19.3 & 26.7 & 35.1 & 47.2 & 35.8 & 32.4 & 40.7 & 40.8 \\
\hline Trade balance & 30.4 & 36.4 & 42.6 & 46.1 & 26.5 & 30.0 & 41.7 & 51.5 \\
\hline Exports, f.o.b. & 199.0 & 232.7 & 274.7 & 302.5 & 341.7 & 272.4 & 347.9 & 385.6 \\
\hline Imports, f.o.b. & -168.6 & -196.3 & -232.2 & -256.4 & -315.2 & -242.4 & -306.2 & -334.1 \\
\hline Services balance & -1.5 & 0.4 & 1.2 & 10.1 & 13.6 & 8.5 & 6.6 & -2.1 \\
\hline Exports & 48.4 & 55.7 & 66.3 & 84.8 & 100.8 & 90.7 & 98.3 & 92.7 \\
\hline Imports & -49.9 & -55.3 & -65.1 & -74.7 & -87.3 & -82.2 & -91.7 & -94.7 \\
\hline Income balance & -8.2 & -8.7 & -7.0 & -6.8 & -1.4 & -3.1 & -4.1 & -4.4 \\
\hline Receipts & 21.2 & 29.1 & 39.1 & 57.3 & 56.1 & 52.7 & 61.2 & 63.1 \\
\hline Payments & -29.4 & -37.8 & -46.1 & -64.2 & -57.5 & -55.7 & -65.3 & -67.5 \\
\hline Transfer payments (net) & -1.4 & -1.4 & -1.7 & -2.2 & -2.8 & -3.0 & -3.5 & -4.3 \\
\hline Capital and financial account balance & -7.5 & -16.9 & -15.1 & -31.6 & -24.3 & -20.6 & -29.6 & -33.4 \\
\hline Capital account (net) & -0.2 & -0.2 & -0.2 & -0.3 & -0.3 & -0.3 & -0.3 & -0.4 \\
\hline Financial account (net) & -7.3 & -16.7 & -14.8 & -31.3 & -24.0 & -20.3 & -29.2 & -33.0 \\
\hline Direct investment & 10.2 & 4.2 & 10.2 & 8.1 & 19.4 & 10.8 & 12.2 & 12.7 \\
\hline Assets & -10.8 & -11.2 & -18.8 & -27.6 & 8.5 & -6.0 & -4.1 & -4.5 \\
\hline Liabilities & 21.0 & 15.5 & 29.0 & 35.7 & 10.9 & 16.8 & 16.3 & 17.3 \\
\hline Portfolio investment & -5.6 & 0.8 & -0.5 & -17.9 & -40.3 & -30.2 & -43.6 & -49.2 \\
\hline Assets & -7.1 & -5.4 & -13.0 & -37.2 & -28.1 & -24.4 & -35.3 & -39.9 \\
\hline Liabilities & 1.5 & 6.3 & 12.5 & 19.3 & -12.1 & -5.7 & -8.3 & -9.3 \\
\hline Other investment & -12.0 & -21.7 & -24.6 & -21.6 & -3.1 & -0.9 & 2.1 & 3.5 \\
\hline Assets & -27.9 & -33.3 & -55.6 & -78.3 & -48.4 & -4.1 & -67.8 & -47.5 \\
\hline Liabilities & 15.9 & 11.6 & 31.0 & 56.7 & 45.3 & 3.2 & 70.0 & 51.0 \\
\hline Net errors and omissions & 0.4 & 2.4 & -3.0 & 3.9 & 1.6 & -0.5 & 0.0 & 0.0 \\
\hline Overall balance & 12.1 & 12.3 & 17.0 & 19.4 & 13.1 & 11.3 & 11.1 & 7.4 \\
\hline \multicolumn{9}{|l|}{ Memorandum items: } \\
\hline GDP in billions of U.S. dollar & 112.7 & 125.4 & 145.1 & 176.8 & 193.3 & 182.2 & 219.0 & 234.3 \\
\hline Current account as percent of GDP & 17.1 & 21.3 & 24.2 & 26.7 & 18.5 & 17.8 & 18.6 & 17.4 \\
\hline Trade balance as percent of GDP & 27.0 & 29.0 & 29.3 & 26.1 & 13.7 & 16.5 & 19.0 & 22.0 \\
\hline \multicolumn{9}{|l|}{ Net international investment position } \\
\hline (In billions of U.S. dollars) 2/ & 219.2 & 255.0 & 339.1 & 359.2 & 339.9 & 438.1 & $\ldots$ & $\ldots$ \\
\hline (In percent of GDP) & 194.5 & 203.4 & 233.8 & 203.2 & 175.8 & 240.4 & $\ldots$ & $\ldots$ \\
\hline
\end{tabular}

Sources: Monetary Authority of Singapore, Economic Survey of Singapore; and staff estimates and projections

1/ Data for the current account balance, the capital and financial account balance, and net errors and omissions are converted to U.S. dollars from the official presentation in Singapore dollars using period-average exchange rate.

2/ See Annex II. 
Table 3. Singapore: Monetary Survey, 2007-10

\begin{tabular}{|c|c|c|c|c|c|c|c|c|c|c|c|c|c|}
\hline & \multicolumn{4}{|c|}{2007} & \multicolumn{4}{|c|}{2008} & \multicolumn{4}{|c|}{2009} & \multirow{2}{*}{$\begin{array}{l}2010 \\
\text { Mar }\end{array}$} \\
\hline & Mar. & Jun. & Sep. & Dec. & Mar. & Jun. & Sep. & Dec. & Mar. & Jun. & Sep. & Dec. & \\
\hline & \multicolumn{13}{|c|}{ (In billions of Singapore dollars, end of period) } \\
\hline Net foreign assets & 239.4 & 239.4 & 238.2 & 238.2 & 252.5 & 251.8 & 256.9 & 262.8 & 274.6 & 293.9 & 300.8 & 294.6 & 293.2 \\
\hline Monetary authorities 1/ & 207.0 & 218.6 & 224.4 & 232.7 & 243.0 & 238.6 & 240.4 & 248.6 & 251.4 & 249.2 & 252.9 & 260.7 & 272.7 \\
\hline Deposit money banks 2/ & 32.4 & 20.8 & 13.8 & 5.5 & 9.5 & 13.2 & 16.5 & 14.2 & 23.2 & 44.7 & 47.9 & 33.9 & 20.5 \\
\hline Domestic credit & 266.5 & 276.5 & 290.6 & 299.2 & 316.0 & 326.5 & 332.2 & 341.6 & 346.8 & 353.2 & 359.8 & 362.2 & 372.7 \\
\hline Claims on private sector & 205.0 & 212.3 & 220.1 & 232.8 & 245.1 & 254.4 & 264.6 & 268.1 & 266.4 & 267.0 & 270.0 & 273.5 & 279.0 \\
\hline Nonbank lending & 201.4 & 209.1 & 218.7 & 233.4 & 249.3 & 261.1 & 272.9 & 272.2 & 270.7 & 272.2 & 275.9 & 281.3 & 286.3 \\
\hline Claims on central government & 61.5 & 64.2 & 70.5 & 66.4 & 70.9 & 72.1 & 67.6 & 73.6 & 80.4 & 86.2 & 89.8 & 88.7 & 93.6 \\
\hline Other items (net) $3 /$ & -226.0 & -222.3 & -234.6 & -239.8 & -255.3 & -262.6 & -264.4 & -271.0 & -272.1 & -290.8 & -299.2 & -285.6 & -285.9 \\
\hline M3 & 286.8 & 301.3 & 302.7 & 306.8 & 322.7 & 325.1 & 333.8 & 342.4 & 357.9 & 364.4 & 368.9 & 378.5 & 387.1 \\
\hline \multirow[t]{2}{*}{ M2 } & 279.8 & 293.6 & 294.1 & 297.6 & 313.3 & 315.7 & 324.7 & 333.4 & 349.3 & 356.3 & 361.4 & 371.2 & 380.0 \\
\hline & \multicolumn{13}{|c|}{ (Annual percentage change) } \\
\hline Domestic credit & 11.0 & 10.9 & 13.6 & 16.7 & 18.6 & 18.1 & 14.3 & 14.2 & 9.7 & 8.2 & 8.3 & 6.0 & 7.5 \\
\hline Claims on private sector & 8.4 & 9.7 & 11.5 & 16.9 & 19.6 & 19.8 & 20.2 & 15.2 & 8.7 & 5.0 & 2.0 & 2.0 & 4.7 \\
\hline Nonbank lending & 10.3 & 10.3 & 12.8 & 19.9 & 23.8 & 24.9 & 24.8 & 16.6 & 8.6 & 4.2 & 1.1 & 3.4 & 5.8 \\
\hline M3 & 22.8 & 23.6 & 20.4 & 14.1 & 12.5 & 7.9 & 10.3 & 11.6 & 10.9 & 12.1 & 10.5 & 10.6 & 8.2 \\
\hline \multirow[t]{2}{*}{ M2 } & 23.0 & 23.6 & 20.0 & 13.4 & 11.9 & 7.5 & 10.4 & 12.0 & 11.5 & 12.9 & 11.3 & 11.3 & 8.8 \\
\hline & \multicolumn{13}{|c|}{ (Contribution to M3 growth, in percent) } \\
\hline Net foreign assets & 15.5 & 12.1 & 7.7 & 5.3 & 4.6 & 4.1 & 6.2 & 8.0 & 6.8 & 13.0 & 13.2 & 9.3 & 5.2 \\
\hline Domestic credit (net) & 11.3 & 11.1 & 13.9 & 15.9 & 17.3 & 16.6 & 13.7 & 13.8 & 9.5 & 8.2 & 8.3 & 6.0 & 7.2 \\
\hline Claims on private sector & 6.8 & 7.7 & 9.0 & 12.5 & 14.0 & 14.0 & 14.7 & 11.5 & 6.6 & 3.9 & 1.6 & 1.6 & 3.5 \\
\hline Claims on central government (net) & 4.4 & 3.4 & 4.8 & 3.4 & 3.3 & 2.6 & -1.0 & 2.3 & 2.9 & 4.3 & 6.7 & 4.4 & 3.7 \\
\hline Other items (net) $3 /$ & -4.0 & 0.4 & -1.1 & -7.1 & -9.3 & -12.8 & -9.6 & -10.2 & -5.5 & -9.1 & -10.9 & -4.7 & -4.3 \\
\hline
\end{tabular}

Source: IMF, International Financial Statistics; and CEIC Data Co., Ltd.

1/ Total foreign reserves (international liquidity concept) minus foreign liabilities

2/ Commercial banks.

3/ Including other nonbank financial institutions. 
Table 4. Singapore: Indicators of Vulnerability, 2004-09

\begin{tabular}{|c|c|c|c|c|c|c|}
\hline & 2004 & 2005 & 2006 & 2007 & 2008 & 2009 \\
\hline \multicolumn{7}{|l|}{ Financial sector indicators } \\
\hline Broad money (M3, percent change, y/y) & 6.1 & 6.4 & 19.1 & 14.1 & 11.6 & 10.6 \\
\hline Private sector credit (percent change, y/y) & 4.4 & 2.0 & 4.9 & 16.9 & 15.2 & 2.0 \\
\hline Credit to the property sector (percent change, $y / y$ ) & 8.2 & 3.1 & 5.5 & 23.4 & 17.1 & 8.3 \\
\hline Share of property-sector credit in total nonbank credit (percen & 46.0 & 46.4 & 46.1 & 47.4 & 47.6 & 49.9 \\
\hline Credit rating of local banks (S\&P) 1/ & $A+$ & $A+/ A A-$ & $A+/ A A-$ & $A+/ A A-$ & $A+/ A A-$ & $A+/ A A-$ \\
\hline Three-month interbank rate (percent, end-year) & 1.4 & 3.3 & 3.4 & 2.4 & 1.0 & 0.7 \\
\hline NPL ratio (local banks, percent) 2/ 3/ & 5.0 & 3.8 & 2.8 & 1.5 & 1.7 & 2.3 \\
\hline Capital adequacy ratio of local banks (percent) $3 /$ & 16.2 & 15.8 & 15.4 & 13.5 & 14.7 & 16.5 \\
\hline \multicolumn{7}{|l|}{ Asset market indicators } \\
\hline Stock prices (percent change, y/y) & 15.6 & 14.0 & 28.0 & 18.7 & -49.2 & 64.5 \\
\hline $\mathrm{P} / \mathrm{E}$ ratio & 16.6 & 15.4 & 19.4 & 18.0 & 6.2 & 19.3 \\
\hline Stock prices of the finance sector (percent change, $y / y$ ) & 9.8 & 5.9 & 29.3 & 8.0 & -52.7 & 73.6 \\
\hline \multicolumn{7}{|l|}{ Real estate prices (percent change, $\mathrm{y} / \mathrm{y}$ ) $4 /$} \\
\hline Residential & -0.4 & 2.9 & 7.1 & 23.6 & 12.3 & -14.1 \\
\hline Office space & -5.4 & 3.4 & 10.2 & 28.1 & 10.3 & -20.0 \\
\hline \multicolumn{7}{|l|}{ External indicators } \\
\hline Current account balance (US $\$$ billion) & 19.3 & 26.7 & 35.1 & 47.2 & 35.8 & 32.4 \\
\hline (In percent of GDP) & 17.1 & 21.3 & 24.2 & 26.7 & 18.5 & 17.8 \\
\hline Gross official reserves (US\$ billion) & 112.6 & 116.2 & 136.3 & 163.0 & 174.2 & 187.8 \\
\hline (In month of next year's imports of goods and services) & 5.4 & 4.7 & 4.9 & 4.9 & 6.4 & 5.7 \\
\hline Real exchange rate (end of period, $2000=100$ ) & 91.7 & 93.2 & 95.2 & 97.4 & 102.5 & 101.5 \\
\hline
\end{tabular}

Sources: Data provided by the Singapore authorities; and IMF, Information Notice System.

1/ Ratings of the three major local banks.

2/ In percent of global nonbank loans.

3/ Latest observation as of September 2009.

4/ The underlying price indices are computed based on the Laspeyres method and are 4-quarter moving averages. 
Table 5. Singapore: Summary of Government Operations, 2005/06-2010/11 1/

(In percent of GDP)

\begin{tabular}{|c|c|c|c|c|c|c|c|}
\hline & \multirow[t]{2}{*}{ 2005/06 } & \multirow[t]{2}{*}{ 2006/07 } & \multirow[t]{2}{*}{$2007 / 08$} & \multirow[t]{2}{*}{$2008 / 09$} & \multicolumn{2}{|c|}{$2009 / 10$} & \multirow{2}{*}{$\begin{array}{r}2010 / 11 \\
\text { Budget }\end{array}$} \\
\hline & & & & & Budget & Prel. & \\
\hline Total revenue & 20.2 & 20.2 & 24.1 & 24.1 & 19.2 & 18.9 & 18.7 \\
\hline Current revenue & 17.1 & 16.6 & 18.7 & 20.4 & 15.7 & 17.0 & 16.8 \\
\hline Tax revenue & 12.0 & 12.1 & 13.5 & 14.1 & 11.2 & 13.0 & 12.6 \\
\hline Investment income 2/ & 3.9 & 3.4 & 3.9 & 5.1 & 3.5 & 3.0 & 3.1 \\
\hline Other nontax revenue & 1.2 & 1.0 & 1.3 & 1.3 & 0.9 & 1.0 & 1.1 \\
\hline Capital revenue $3 /$ & 3.1 & 3.6 & 5.4 & 3.6 & 3.5 & 1.9 & 1.9 \\
\hline Total expenditure & 12.4 & 13.4 & 12.4 & 18.5 & 21.2 & 20.8 & 21.0 \\
\hline Current expenditure & 10.8 & 12.0 & 11.1 & 14.1 & 14.9 & 14.3 & 13.8 \\
\hline Operating expenditure & 10.0 & 9.9 & 9.5 & 10.8 & 11.7 & 11.5 & 11.4 \\
\hline Debt servicing & 0.1 & 0.1 & 0.0 & 0.0 & 0.0 & 0.0 & 0.0 \\
\hline Agency fees on land sales & 0.0 & 0.0 & 0.0 & 0.0 & 0.0 & 0.0 & 0.0 \\
\hline Investment expenses & 0.4 & 0.7 & 0.9 & 1.3 & 1.1 & 0.9 & 0.9 \\
\hline Transfer payments & 0.3 & 1.3 & 0.7 & 2.1 & 2.1 & 1.9 & 1.6 \\
\hline Development expenditure and net lending & 1.5 & 1.1 & 1.1 & 3.8 & 6.3 & 6.3 & 7.0 \\
\hline Development expenditure 4/ & 3.6 & 2.7 & 2.8 & 4.1 & 5.0 & 5.3 & 5.6 \\
\hline Net lending & -2.1 & -1.6 & -1.7 & -0.3 & 1.3 & 1.1 & 1.4 \\
\hline Fund transfers $5 /$ & 0.1 & 0.2 & 0.1 & 0.6 & 0.1 & 0.1 & 0.1 \\
\hline Overall balance & 7.8 & 6.9 & 11.7 & 5.6 & -2.0 & -1.9 & -2.3 \\
\hline Primary balance $6 /$ & -1.1 & -1.5 & 0.8 & -2.9 & -7.7 & -5.6 & -5.8 \\
\hline \multicolumn{8}{|l|}{ Memorandum items: } \\
\hline Budget balance (the government's definition) & 0.7 & 0.0 & 2.8 & 0.1 & -3.6 & -1.0 & -1.0 \\
\hline Government saving & 6.2 & 4.3 & 7.5 & 5.7 & 0.7 & 2.6 & 2.9 \\
\hline Structural primary balance $7 /$ & -1.2 & -2.0 & 0.1 & -2.9 & -6.8 & -4.7 & -5.4 \\
\hline
\end{tabular}

Sources: Data provided by the Singapore authorities; and staff estimates and projections.

1/ Fiscal year runs from April 1 through March 31.

2/ Includes investment income from government assets (interest rates and dividends), including interest earnings on development loans from 2000/01.

3/ Sale of government property.

4/ Includes the land reclamation expenditure.

5/ Includes transfers to the Endowment Funds: Edusave, Medical, Lifelong Learning, and ElderCare.

6/ Overall balance excluding investment income, capital revenue, debt service, net lending, and fund transfers.

7/ Primary balance adjusted for cyclical impact on revenues associated with deviation between

actual and potential economic output. 
Table 6. Singapore: Medium-Term Scenario, 2005-15

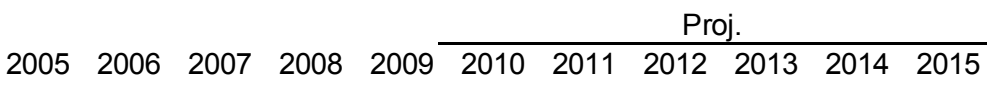

Real growth (percent change)

GDP

Total domestic demand

Final domestic demand

Consumption

Private

Public

Gross capital formation

Private

Public

Net exports /1

$\begin{array}{rrrrrrrrrrr}7.4 & 8.6 & 8.5 & 1.8 & -1.3 & 9.9 & 4.9 & 4.5 & 4.4 & 4.3 & 4.0 \\ 2.6 & 7.1 & 7.8 & 14.7 & -4.9 & 9.0 & 5.7 & 5.7 & 5.5 & 5.4 & 4.9 \\ 2.8 & 7.1 & 10.2 & 7.2 & 0.1 & 13.5 & 5.4 & 5.4 & 5.2 & 5.1 & 4.7 \\ 3.9 & 4.0 & 5.7 & 3.9 & 2.1 & 6.5 & 6.1 & 5.3 & 4.9 & 4.7 & 4.1 \\ 3.6 & 3.1 & 6.5 & 2.7 & 0.4 & 5.8 & 6.0 & 5.6 & 5.2 & 5.0 & 4.6 \\ 5.2 & 7.3 & 3.0 & 8.4 & 8.2 & 8.8 & 6.5 & 4.5 & 4.1 & 3.8 & 2.6 \\ -0.4 & 15.1 & 12.4 & 38.0 & -16.1 & 12.3 & 5.1 & 6.4 & 6.5 & 6.5 & 6.4 \\ 0.2 & 21.2 & 15.9 & 37.7 & -18.4 & 12.5 & 5.1 & 6.9 & 7.1 & 7.2 & 7.0 \\ -3.4 & -12.5 & -9.6 & 40.4 & 1.6 & 10.6 & 4.8 & 3.5 & 2.4 & 2.1 & 2.0 \\ 5.4 & 3.4 & 4.7 & -9.0 & 2.3 & 3.4 & 0.5 & 0.1 & 0.1 & 0.1 & 0.1\end{array}$

Saving and investment (percent of GDP)

Gross national savings

Central government

Private and other

Gross capital formation

$\begin{array}{lllllllllll}41.3 & 45.0 & 47.9 & 48.5 & 45.0 & 46.4 & 45.1 & 44.3 & 43.9 & 43.7 & 43.2\end{array}$

$\begin{array}{lllllllllll}6.1 & 4.9 & 6.7 & 6.2 & 3.4 & 4.1 & 4.6 & 4.8 & 4.9 & 5.0 & 4.9\end{array}$

$\begin{array}{lllllllllll}35.1 & 40.1 & 41.1 & 42.3 & 41.6 & 42.3 & 40.5 & 39.5 & 39.0 & 38.7 & 38.3\end{array}$

$\begin{array}{lllllllllll}20.0 & 20.8 & 21.2 & 29.9 & 27.2 & 27.8 & 27.7 & 27.9 & 28.2 & 28.5 & 29.2\end{array}$

Inflation and unemployment

(period average, percent)

CPI inflation

Unemployment rate

Output gap

$\begin{array}{lllllllllll}0.5 & 1.0 & 2.1 & 6.6 & 0.6 & 2.5 & 2.1 & 2.1 & 2.1 & 2.1 & 2.0\end{array}$

$\begin{array}{lllllllllll}3.1 & 2.7 & 2.1 & 2.2 & 3.0 & 2.2 & 2.3 & 2.3 & 2.3 & 2.1 & 2.1\end{array}$

$\begin{array}{lllllllllll}0.1 & 2.2 & 4.7 & 1.5 & -4.0 & 0.1 & 0.5 & 0.7 & 0.4 & 0.3 & 0.0\end{array}$

Central government (percent of GDP) 2/

Revenue

Expenditure

Overall balance

Primary balance

$\begin{array}{lllllllllll}20.0 & 20.2 & 23.1 & 24.1 & 20.1 & 20.3 & 21.0 & 21.2 & 21.3 & 21.3 & 20.5\end{array}$

$\begin{array}{lllllllllll}12.8 & 13.0 & 12.6 & 17.0 & 20.2 & 20.5 & 20.8 & 20.7 & 20.6 & 20.4 & 19.6\end{array}$

$\begin{array}{rrrrrrrrrrr}7.3 & 7.1 & 10.5 & 7.1 & -0.1 & -0.2 & 0.2 & 0.5 & 0.7 & 0.9 & 0.9\end{array}$

$\begin{array}{lllllllllll}-1.3 & -1.4 & 0.3 & -1.9 & -4.9 & -4.2 & -4.3 & -4.3 & -4.2 & -4.0 & -3.9\end{array}$

Merchandise trade (percent change)

Export volume

Import volume

Terms of trade

$\begin{array}{lllllllllll}12.0 & 11.4 & 7.4 & 3.0 & -10.3 & 10.0 & 8.8 & 8.4 & 7.9 & 7.3 & 7.1\end{array}$

$\begin{array}{lllllllllll}9.5 & 11.0 & 6.5 & 9.6 & -12.7 & 7.1 & 6.8 & 6.6 & 6.5 & 6.2 & 6.8\end{array}$

$\begin{array}{lllllllllll}-2.0 & -1.1 & -0.9 & -1.1 & 1.0 & -1.6 & -0.2 & 0.1 & 0.1 & 0.2 & 0.3\end{array}$

Balance of payments (percent of GDP)

Current account balance

$\begin{array}{lllllllllll}21.3 & 24.2 & 26.7 & 18.5 & 17.8 & 18.6 & 17.4 & 16.5 & 15.7 & 15.2 & 14.0\end{array}$

$\begin{array}{lllllllllll}29.4 & 30.2 & 31.8 & 20.7 & 21.1 & 22.0 & 21.1 & 20.5 & 19.9 & 19.5 & 18.4\end{array}$

$\begin{array}{lllllllllll}-8.1 & -6.0 & -5.1 & -2.2 & -3.3 & -3.5 & -3.7 & -4.1 & -4.2 & -4.3 & -4.4\end{array}$

Balance on income and transfers

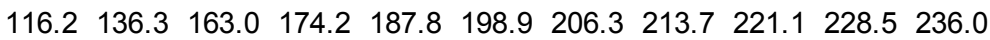

Gross official reserves (US $\$$ billions)

$\begin{array}{lllllllllll}(4.7) & (4.9) & (4.9) & (6.4) & (5.7) & (5.6) & (5.4) & (5.2) & (5.0) & (4.9) & \text { (4.9) }\end{array}$

(In months of imports) 3/

Sources: Data provided by the Singapore authorities; and staff estimates and projections.

1/ Contribution to GDP growth.

2/ On a calendar year basis.

$3 /$ In months of next year's imports of goods and services. 
Table 7. Singapore: Financial Soundness Indicators: Local Banking Sector, 2005-09

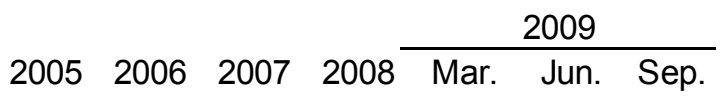

(In percent)

Capital adequacy ratio

Regulatory capital to risk-weighted assets

$\begin{array}{rrrrrrr}15.8 & 15.4 & 13.5 & 14.7 & 16.7 & 16.5 & 16.5\end{array}$

Regulatory tier I capital to risk-weighted assets

$\begin{array}{lllllll}11.4 & 11.2 & 9.8 & 11.5 & 13.1 & 13.3 & 13.5\end{array}$

Shareholders' equity to assets

$\begin{array}{lllllll}9.6 & 9.6 & 9.2 & 8.3 & 9.6 & 10.2 & 10.5\end{array}$

Asset quality

NPLs to nonbank loans

Total provisions to NPLs

Specific provisions to NPLs

$\begin{array}{lllllll}3.8 & 2.8 & 1.5 & 1.7 & 2.0 & 2.5 & 2.3\end{array}$

$\begin{array}{lllllll}78.7 & 89.5 & 115.6 & 109.1 & 96.8 & 83.9 & 91.0\end{array}$

$\begin{array}{lllllll}40.4 & 41.3 & 39.9 & 43.7 & 40.4 & 34.8 & 38.0\end{array}$

Loan concentrations (in percent of total loans)

Bank loans

Non-bank loans

Of which:

Manufacturing loans

Building and construction loans

Housing loans

Loans to professionals and private individuals

Loans to nonbank financial institutions

$\begin{array}{lllllll}24.1 & 22.8 & 16.2 & 13.8 & 14.9 & 17.2 & 17.0\end{array}$

$\begin{array}{lllllll}75.9 & 77.2 & 83.8 & 86.2 & 85.1 & 82.9 & 83.0\end{array}$

$\begin{array}{lllllll}7.6 & 8.4 & 9.2 & 9.2 & 9.0 & 8.1 & 8.2\end{array}$

$\begin{array}{lllllll}8.8 & 9.5 & 11.4 & 13.2 & 13.0 & 12.5 & 12.1\end{array}$

$\begin{array}{llllllll}21.7 & 21.0 & 20.6 & 20.3 & 20.0 & 20.0 & 20.8\end{array}$

$\begin{array}{llllllll}9.4 & 8.7 & 8.6 & 8.5 & 8.3 & 8.4 & 8.4\end{array}$

$\begin{array}{lllllll}10.0 & 10.5 & 12.3 & 11.7 & 12.1 & 11.7 & 11.3\end{array}$

\section{Profitability}

After-tax return on assets

$\begin{array}{lllllll}1.2 & 1.4 & 1.3 & 1.0 & 1.0 & 1.1 & 1.1\end{array}$

After-tax return on equity

$\begin{array}{lllllll}11.2 & 13.7 & 12.9 & 10.7 & 11.4 & 11.2 & 11.0\end{array}$

Net interest margin

$\begin{array}{lllllll}1.9 & 2.1 & 2.1 & 2.2 & 2.3 & 2.2 & 2.2\end{array}$

Non-interest income to total income

$\begin{array}{lllllll}39.0 & 42.6 & 39.1 & 32.2 & 37.0 & 37.9 & 35.7\end{array}$

Liquidity

Liquid DBU assets to total DBU assets

$\begin{array}{lllllll}10.3 & 9.8 & 10.1 & 9.8 & 10.2 & 10.4 & 10.7\end{array}$

Liquid DBU assets to total DBU liabilities

$\begin{array}{lllllll}11.3 & 10.6 & 10.8 & 10.7 & 11.1 & 11.2 & 11.6\end{array}$

Source: Monetary Authority of Singapore. 


\section{INTERNATIONAL MONETARY FUND}

\section{SINGAPORE}

Staff Report for the 2010 Article IV Consultation-Informational Annex

Prepared by the Asia and Pacific Department

July 1,2010

Contents

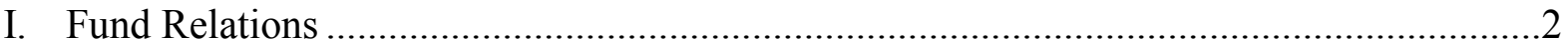

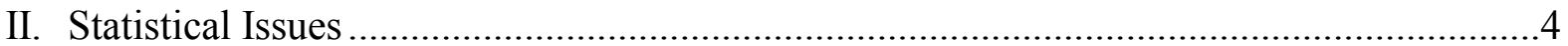




\section{ANNEX I: SINGAPORE-FUND RELATIONS}

(As of May 31, 2010)

I. Membership Status: Joined August 3, 1966; Article VIII

II. General Resources Account:

Quota

Fund holdings of currency

Reserve position in Fund

III. SDR Department:

Net cumulative allocation

Holdings
SDR Million

862.50

694.92

167.64

SDR Million

744.21

980.85
Quota

(In percent)

100.00

80.57

19.44
Allocation
(In percent)
100.00
131.80

IV. Outstanding Purchases and Loans: None

V. Financial Arrangements: None

VI. Projected Payments to Fund: None

\section{Exchange Arrangement:}

Singapore's exchange rate is classified as "other managed." The Monetary Authority of Singapore (MAS) monitors its value against an undisclosed basket of currencies and intervenes in the market to maintain this value within an undisclosed target band. The U.S. dollar is the intervention currency.

Singapore has accepted the obligations of Article VIII, Sections 2, 3, and 4 and maintains an exchange rate system that is free of restrictions on the making of payments and transfers for current international transactions.

Singapore maintains restrictions on Singapore-dollar credit facilities to, and bond and equity issuance by, nonresident financial institutions. Singapore-dollar proceeds obtained by nonresident financial entities (such as banks, merchant banks, finance companies, and hedge funds) from loans exceeding S\$5 million, or any amount for equity listings or bond issuance to finance activities outside Singapore have to be swapped or converted into foreign currency upon draw-down. Financial institutions are prohibited from extending Singapore-dollar credit 
facilities in excess of $\mathbf{S} \$ 5$ million to nonresident financial entities if there is reason to believe that the Singapore-dollar proceeds may be used for Singapore-dollar currency speculation.

\section{Article IV Consultation:}

Singapore is on the 12-month consultation cycle. The 2009 Article IV consultation discussions were held during May 11-18, 2009, the Executive Board discussed the staff report (IMF Country Report No. 09/269) and concluded the consultation on July 29, 2009.

\section{FSAP Participation and ROSCs:}

The FSAP was undertaken in conjunction with the 2003 Article IV consultation. The FSSA was published as IMF Country Report No. 04/104.

A fiscal ROSC remains a priority for the authorities, and the exact timing is likely to be considered in 2011. A data ROSC could also be considered at that time.

X. Technical Assistance: None

XI. Resident Representative: Mr. Ravi Balakrishnan 


\title{
ANNEX II: SingAPORE-STATISTICAL ISSUES
}

\author{
As of June 17, 2010
}

\section{Assessment of Data Adequacy for Surveillance}

General: Data provision is broadly adequate for surveillance. While the authorities have continued to improve the quality of data, dissemination of more disaggregated data would enhance the basis for macroeconomic policy analysis, particularly in the external and fiscal areas.

National accounts: The Singapore Department of Statistics (DOS) has made improvements in data sources and methodology. The reconciliation of various national accounts estimates was conducted in 2006, resulting in lower statistical discrepancies. (DOS) has completed the rebasing of the Singapore's national accounts to reference year 2005 .

Price statistics: DOS has completed the rebasing of the Consumer Price Index (CPI) to base year 2009. The $\mathrm{CPI}$ is rebased once every five years to reflect the latest consumption pattern and composition of goods and services consumed by resident households.

Government finance statistics: Information on government assets held abroad is neither published nor provided to the Fund. Interest and dividend on these assets and debt service payments on domestic debt made from the extra budgetary Government Securities Fund are published on an annual basis. Data on the financial position of the consolidated public sector are not published.

Monetary statistics: The Monetary Authority of Singapore has not submitted the standardized report forms (SRFs) for monetary statistics introduced in October 2004. The SRFs provide for accounting data to be broken down by instrument, sector, and currency.

Balance of payments: Data on the international investment position (IIP) are not provided on a disaggregated level as suggested by the Balance of Payments Manual (5th edition). Also, the IIP position does not include all the net foreign assets held by Singapore's Government Investment Corporation, although the associated flows are included in the balance of payments data. The authorities are improving over time the reporting of the international investment position to the IMF.

\section{Data Standards and Quality}

Singapore provides data on a timely basis and meets No data ROSC is available. all the SDDS specifications. These include the coverage, periodicity, and timeliness of the data; and the dissemination of advance release calendars; quarterly certification of the metadata posted on the Fund's Dissemination Standards Bulletin Board; and provision of information to allow users to assess data quality. 


\section{Singapore-Table of Common Indicators Required for Surveillance}

\section{(As of June 8, 2010)}

\begin{tabular}{|c|c|c|c|c|c|}
\hline & $\begin{array}{c}\text { Date of } \\
\text { Latest } \\
\text { Observation }\end{array}$ & $\begin{array}{c}\text { Date } \\
\text { Received }\end{array}$ & $\begin{array}{c}\text { Frequency } \\
\text { of } \\
\text { Data }^{6}\end{array}$ & $\begin{array}{l}\text { Frequency } \\
\text { of } \\
\text { Reporting }^{6}\end{array}$ & $\begin{array}{l}\text { Frequency of } \\
\text { Publication }^{6}\end{array}$ \\
\hline Exchange rates & 06/08/10 & 06/08/10 & $\mathrm{D}$ & $\mathrm{D}$ & D \\
\hline $\begin{array}{l}\text { International reserve assets and reserve } \\
\text { liabilities of the Monetary Authorities }{ }^{1}\end{array}$ & $05 / 2010$ & 06/2010 & M & M & M \\
\hline Reserve/base money & $05 / 2010$ & 06/2010 & M & M & M \\
\hline Broad money & $04 / 2010$ & 06/2010 & M & M & M \\
\hline Central bank balance sheet & $04 / 2010$ & 06/2010 & M & M & M \\
\hline $\begin{array}{l}\text { Consolidated balance sheet of the } \\
\text { banking system }\end{array}$ & $04 / 2010$ & $06 / 2010$ & M & M & M \\
\hline Interest rates ${ }^{2}$ & 06/08/10 & 06/08/10 & $\mathrm{D}$ & $\mathrm{D}$ & $\mathrm{D}$ \\
\hline Consumer price index & $04 / 2010$ & $05 / 2010$ & M & M & M \\
\hline $\begin{array}{l}\text { Revenue, expenditure, balance and } \\
\text { composition of financing }{ }^{3} \text { - general } \\
\text { government }^{4}\end{array}$ & $\cdots$ & $\ldots$ & $\ldots$ & $\ldots$ & $\ldots$ \\
\hline $\begin{array}{l}\text { Revenue, expenditure, balance and } \\
\text { composition of financing }{ }^{3} \text { - central } \\
\text { government }\end{array}$ & $04 / 2010$ & 05/2010 & M & M & M \\
\hline $\begin{array}{l}\text { Stocks of central government and } \\
\text { central government-guaranteed debt }\end{array}$ & $\cdots$ & $\cdots$ & $\ldots$ & $\ldots$ & $\ldots$ \\
\hline External current account balance & 2010:Q1 & $05 / 2010$ & Q & Q & Q \\
\hline $\begin{array}{l}\text { Exports and imports of goods and } \\
\text { services }\end{array}$ & $04 / 2010$ & 05/2010 & M & M & M \\
\hline GDP/GNP & 2010:Q1 & $05 / 2010$ & Q & Q & Q \\
\hline Gross external debt ${ }^{7}$ & 2009:Q4 & $03 / 2010$ & Q & Q & Q \\
\hline Net international investment position ${ }^{8}$ & 2008 & 2009 & A & A & A \\
\hline
\end{tabular}

${ }^{1}$ Includes reserve assets pledged or otherwise encumbered as well as net derivative positions.

${ }^{2}$ Both market-based and officially determined, including discount rates, money market rates, rates on treasury bills, notes, and bonds.

${ }^{3}$ Foreign, domestic bank, and domestic nonbank financing.

${ }^{4}$ The general government consists of the central government (budgetary funds, extra budgetary funds, and social security funds) and state and local governments.

${ }^{5}$ Including currency and maturity composition.

${ }^{6}$ Daily (D); weekly (W); monthly (M); quarterly (Q); annually (A); irregular (I); and not available (NA).

${ }^{7}$ Official external debt is zero.

${ }^{8}$ The reported number does not include the net foreign asset position of the Government of Singapore's Investment Corporation. 


\section{Statement by the IMF Staff Representative on Singapore July 16, 2010}

The information below has become available following the issuance of the staff report. It does not alter the thrust of the staff appraisal.

\section{Recent Data}

- $\quad$ The economy continued to expand strongly in the second quarter. On advance estimates released on July 14, GDP growth jumped to 26 percent and 19.3 percent, following (revised) growth of 45.9 percent (q/q s.a.a.r.) and 16.9 percent $(\mathrm{y} / \mathrm{y})$, in the previous three months. The pace of activity in the second quarter was the fastest on record. Double digit growth was recorded in all main sectors. Manufacturing benefitted from a spike in the production of pharmaceuticals and electronics; and services were boosted by tourism and increased financial intermediation. With oneoff factors at play, growth is expected to revert to a more sustainable rate in the quarters ahead.

- $\quad$ On the basis of better-than-expected performance in the first half of year, the Ministry of Trade and Industry has marked up its projection for 2010 GDP growth to the range 13-15 percent, from 7-9 percent.

2. Outlook. The latest data release makes the staff's projection (which was more upbeat than consensus) somewhat conservative. The flash second-quarter outturn, if confirmed, and the revised first-quarter outturn mechanically lift the GDP numbers for 2010. Accordingly, GDP growth for the year is likely to be revised from about 10 percent to around 15 percent in the upcoming WEO round. 2011 GDP growth will probably be marked down somewhat, on base effects. The strong performance increases upside risks to inflation. 
Public Information Notice (PIN) No. 10/95 FOR IMMEDIATE RELEASE July 23, 2010
International Monetary Fund $70019^{\text {th }}$ Street, NW

Washington, D. C. 20431 USA

\section{IMF Executive Board Concludes 2010 Article IV Consultation with Singapore}

On July 16, 2010, the Executive Board of the International Monetary Fund (IMF) concluded the Article IV consultation with Singapore. ${ }^{1}$

\section{Background}

Singapore's 2008-09 recession turned out less deep than feared. A broad-based expansion is now on. Output losses have been recouped and medium-term issues are again at the top of the policy agenda.

Activity started to shrink in the second quarter of 2008. At its low mark a year later, GDP was 9 percent lower than pre-crisis. The output recovery has been as swift as the contraction. Growth has been double-digit for three of the last four quarters, reaching nearly 39 percent (quarter-on-quarter, seasonally adjusted annualized rate) in the first quarter of this year. Price dynamics have mirrored those of output. Headline inflation declined quickly and turned negative in the second half of 2009. With dissipating base effects, rising fuel and transport costs, and growth above potential, the consumer price index is back to its previous peak.

Although tested, Singapore's financial system withstood the world recession well. As global market volatility subsided, financial activities staged a rapid recovery beginning in

\footnotetext{
${ }^{1}$ Under Article IV of the IMF's Articles of Agreement, the IMF holds bilateral discussions with members, usually every year. A staff team visits the country, collects economic and financial information, and discusses with officials the country's economic developments and policies. On return to headquarters, the staff prepares a report, which forms the basis for discussion by the Executive Board. At the conclusion of the discussion, the Managing Director, as Chairman of the Board, summarizes the views of Executive Directors, and this summary is transmitted to the country's authorities. An explanation of any qualifiers used in summings up can be found here: http://www.imf.org/external/np/sec/misc/qualifiers.htm.
} 
early 2009. Banking and insurance led the way, while brokerage and wealth management were slower in posting gains.

From a historical perspective, Singapore's exit from recession has been more vigorous than those following the 2001 dotcom crash and the 1997-98 Asian crisis. Improved global demand and sentiment as well as strong domestic policies and resilient labor markets have limited the severity of the downturn and set the stage for the expansion underway.

Macroeconomic management started to transition out of crisis-relief mode late last year. Policy normalization has by now been achieved. Monetary, fiscal, and macroprudential policies are appropriately calibrated to sustain the expansion and curb risks in the goods and asset markets. Medium-term issues are again at the top of the policy agenda.

The economy is projected to expand nearly 10 percent in $2010 .^{2}$ Both external and domestic demand should continue to support growth, although the exceptional momentum of the first quarter is bound to wane. As the output gap turns positive, inflation will be trending up, in part because of one-off factors.

\section{Executive Board Assessment}

Executive Directors commended the authorities for the strong fundamentals and policy frameworks developed over time and the forceful countercyclical policies in response to the global downturn. A broad-based recovery is now underway and the focus has rightly shifted to sustaining the expansion. Given Singapore's high exposure to risks from a slowdown of world trade or from financial linkages, flexible and proactive policies continue to be important.

Directors commended the Monetary Authority of Singapore for a skillful unwinding of the monetary stimulus and the restoration of broadly neutral monetary conditions. The return to a modest and gradual appreciation of the Singapore dollar in nominal effective terms is consistent with internal and external stability. Directors pointed out that changes in the outlook for growth or inflation warrant vigilance and could call for a further recalibration of monetary policy in the period ahead.

Directors agreed that Singapore's exchange rate regime remains appropriate and that the exchange-rate centered monetary framework has been an important source of stability in challenging times. They noted the staff's assessment that the Singapore dollar appears to be somewhat weaker than its medium-term equilibrium level, although considerable uncertainty clouds this assessment. They also noted that the Singapore dollar would likely strengthen in real effective terms over time as reforms promote faster productivity growth and the domestic economy continues to expand.

\footnotetext{
2 This projection predates the release of the advance estimate for GDP growth for the second quarter of 2010.
} 
Directors considered that last year's extraordinary fiscal support has been appropriately withdrawn in the 2010 budget and that fiscal settings are now close to neutral and in tune with internal balance. They supported the return of fiscal policy to its traditional medium-term orientation and the emphasis on measures to facilitate innovation, capital deepening, and productivity growth. The authorities' intention to increase spending on physical and social infrastructure is welcome.

Directors agreed that Singapore's strong supervision and risk management systems had been crucial in safeguarding financial stability in the global downturn. They endorsed the plans to unwind by year-end the blanket deposit guarantee and move to a system with higher deposit coverage. The authorities' approach will ensure international consistency among economies with strong linkages. Directors welcomed recent measures to contain risks in exuberant segments of the property market and encouraged continued close monitoring of the situation.

Directors acknowledged the authorities' rationale for promoting self-reliance over social welfare programs, reflecting society's preferences. At the same time, they encouraged the authorities to adapt their approach over time as needed to preserve social and intergenerational fairness. Directors also noted that because of the special features of Singapore's economy, building strong foreign exchange and fiscal reserve buffers has been a central element of economic strategy which has served the country well. They considered that, over time, a slower pace of reserve accumulation could be expected given Singapore's demographic profile going forward.

Public Information Notices (PINs) form part of the IMF's efforts to promote transparency of the IMF's views and analysis of economic developments and policies. With the consent of the country (or countries) concerned, PINs are issued after Executive Board discussions of Article IV consultations with member countries, of its surveillance of developments at the regional level, of post-program monitoring, and of ex post assessments of member countries with longer-term program engagements. PINs are also issued after Executive Board discussions of general policy matters, unless otherwise decided by the Executive Board in a particular case. The staff report (use the free Adobe Acrobat Reader to view this pdf file) for the 2010 Article IV Consultation with Singapore is also available. 
Singapore: Selected Economic and Financial Indicators, 2005-11

\begin{tabular}{|c|c|c|c|c|c|c|c|}
\hline & \multirow[b]{2}{*}{2005} & \multirow[b]{2}{*}{2006} & \multirow[b]{2}{*}{2007} & \multirow[b]{2}{*}{2008} & \multirow[b]{2}{*}{2009} & \multicolumn{2}{|c|}{ Proj. } \\
\hline & & & & & & 2010 & 2011 \\
\hline \multicolumn{8}{|l|}{ Growth (percentage change) } \\
\hline Real GDP & 7.4 & 8.6 & 8.5 & 1.8 & -1.3 & 9.9 & 4.9 \\
\hline Total domestic demand & 2.6 & 7.1 & 7.8 & 14.7 & -4.9 & 9.0 & 5.7 \\
\hline Consumption & 3.9 & 4.0 & 5.7 & 3.9 & 2.1 & 6.5 & 6.1 \\
\hline Private consumption & 3.6 & 3.1 & 6.5 & 2.7 & 0.4 & 5.8 & 6.0 \\
\hline Gross capital formation & -0.4 & 15.1 & 12.4 & 38.0 & -16.1 & 12.3 & 5.1 \\
\hline \multicolumn{8}{|l|}{ Saving and investment (percent of GDP) } \\
\hline Gross national saving & 41.3 & 45.0 & 47.9 & 48.5 & 45.0 & 46.4 & 45.1 \\
\hline Gross domestic investment & 20.0 & 20.8 & 21.2 & 29.9 & 27.2 & 27.8 & 27.7 \\
\hline \multicolumn{8}{|c|}{ Inflation and unemployment (period average, percent) } \\
\hline CPI inflation & 0.5 & 1.0 & 2.1 & 6.6 & 0.6 & 2.5 & 2.1 \\
\hline Unemployment rate & 3.1 & 2.7 & 2.1 & 2.2 & 3.0 & 2.2 & 2.3 \\
\hline \multicolumn{8}{|c|}{ Central government budget (percent of GDP) 1/ } \\
\hline Revenue & 20.0 & 20.2 & 23.1 & 24.1 & 20.1 & 20.3 & 21.0 \\
\hline Expenditure & 12.8 & 13.0 & 12.6 & 17.0 & 20.2 & 20.5 & 20.8 \\
\hline Overall balance & 7.3 & 7.1 & 10.5 & 7.1 & -0.1 & -0.2 & 0.2 \\
\hline Primary operating balance & -1.3 & -1.4 & 0.3 & -1.9 & -4.9 & -4.2 & -4.3 \\
\hline \multicolumn{8}{|c|}{ Money and credit (end of period, percentage change) } \\
\hline Broad money (M3) & 6.4 & 19.1 & 14.1 & 11.6 & 10.6 & $\ldots$ & $\ldots$ \\
\hline Lending to nonbanking sector & 2.2 & 6.3 & 19.9 & 16.6 & 3.4 & $\ldots$ & $\ldots$ \\
\hline Three-month interbank rate( percent) & 3.3 & 3.4 & 2.4 & 1.0 & 0.7 & $\ldots$ & $\ldots$ \\
\hline \multicolumn{8}{|l|}{ Balance of payments (US\$ billions) } \\
\hline Current account balance & $\begin{array}{r}26.7 \\
(213)\end{array}$ & $\begin{array}{r}35.1 \\
(242)\end{array}$ & $\begin{array}{r}47.2 \\
(26.7)\end{array}$ & $\begin{array}{r}35.8 \\
(18.5)\end{array}$ & $\begin{array}{r}32.4 \\
(178)\end{array}$ & $\begin{array}{r}40.7 \\
(186)\end{array}$ & $\begin{array}{r}40.8 \\
(174)\end{array}$ \\
\hline Trade balance & 36.4 & 42.6 & 46.1 & 26.5 & 30.0 & 41.7 & 51.5 \\
\hline Exports, f.o.b. & 232.7 & 274.7 & 302.5 & 341.7 & 272.4 & 347.9 & 385.6 \\
\hline Imports, f.o.b. & -196.3 & -232.2 & -256.4 & -315.2 & -242.4 & -306.2 & -334.1 \\
\hline Financial account balance & -16.7 & -14.8 & -31.3 & -24.0 & -20.3 & -29.2 & -33.0 \\
\hline Overall balance & 12.3 & 17.0 & 19.4 & 13.1 & 11.3 & 11.1 & 7.4 \\
\hline $\begin{array}{l}\text { Gross official reserves (US\$ billions) } \\
\text { (months of imports) } 2 /\end{array}$ & $\begin{array}{r}116.2 \\
(4.7)\end{array}$ & $\begin{array}{r}136.3 \\
(4.9)\end{array}$ & $\begin{array}{r}163.0 \\
(4.9)\end{array}$ & $\begin{array}{r}174.2 \\
(6.4)\end{array}$ & $\begin{array}{r}187.8 \\
(5.7)\end{array}$ & $\begin{array}{r}198.9 \\
(5.6)\end{array}$ & $\begin{array}{r}206.3 \\
(5.4)\end{array}$ \\
\hline
\end{tabular}

Sources: Data provided by the Singapore authorities; and IMF staff estimates and projections.

$1 /$ On a calendar year basis.

$2 /$ In months of following year's imports of goods and services. 


\section{Statement by Adrian Chua, Alternate Executive Director for Singapore July 16, 2010}

\section{Introduction}

1.1 The Singapore authorities would like to thank the IMF staff for the 2010 Article IV Consultation. The discussions during the Consultation, which centred on policies to sustain non-inflationary growth and mitigate risks, were engaging and constructive.

\section{Recent Economic Developments and Outlook}

2.1 After experiencing output loss of 9\% over the course of the recession, economic activity in Singapore staged a rapid and decisive recovery. Over four quarters to March 2010, GDP increased, on average, at a double-digit pace (quarter-on-quarter seasonally-adjusted annualised rate, q-o-q SAAR), confounding initial expectations of a modest recovery. The sharp upturn resulted in GDP contracting by a milder-than-expected $1.3 \%$ in 2009 . With GDP having expanded by a further 38.6\% q-o-q SAAR in Q1 2010, the economy has now recouped all the output lost during the downturn.

2.2 Since Q2 2009, as the external environment improved and global trade flows normalised, Singapore's economic upturn has evolved from one that was driven by inventory restocking and stabilisation of global financial conditions, to a broad-based recovery that reflected the pick-up in final demand in our key export markets. In particular, growth was led by Singapore's trade-related sectors, especially the IT industry. Besides manufacturing output, Singapore also experienced a surge in transport and wholesale trade activities, reflecting its role as a regional trading and logistics hub. At the same time, the financial services sector and tourism industry picked up strongly, amidst the continued resilience in regional demand and improved global financial conditions. Recent indicators in April and May suggest that the growth momentum for trade, industrial production and tourism flows is likely to be sustained in Q2 2010.

2.3 For the rest of 2010, we expect the growth momentum to slow although domestic economic activity will remain at a high level. GDP growth will be supported by the recovery in consumption and investment in some major economies as well as in Asia. Moreover, the Singapore economy will benefit from the launch of new capacity in the manufacturing and services sectors. These include new petrochemicals plants, biologics facilities and the integrated resorts. Notwithstanding the generally sanguine outlook, the authorities are cognizant of the downside risks presented by the uncertainties in the external environment. A key risk is the sovereign debt crisis in the Eurozone, which continues to evolve and bears close monitoring. The Singapore economy will likely moderate to a more sustainable pace of growth next year against the evolving developments in the global economy.

2.4 Domestic CPI inflation was negative in the second half of 2009, reflecting the combined effects of lower global oil prices and domestic business costs as well as weaker domestic consumer demand. However, inflation has since picked up to $0.9 \%$ y-o-y in Q1 2010 and risen further to 3.2\% in April-May. Apart from the effects of the low base last year, the step-up in inflation rate was largely attributed to the rebound in crude oil prices and 
the cost of private transportation. Recently, costs of other items such as food and recreation services had also picked up.

2.5 The headline CPI inflation is likely to remain elevated for the rest of the year, driven largely by higher private road transport costs and commodity prices. Other domestic sources of inflationary pressure could also emerge more strongly in the coming quarters as business costs rise in line with the expansion of the economy and tightening of the factor markets. In particular, labour market conditions have tightened significantly, with the seasonally adjusted resident unemployment rate nearly back to its pre-crisis level. Thus, industries which are unable to step up productivity could face difficulty in absorbing the higher wage costs, which could in turn put upward pressure on the prices of a wide range of goods and services.

Reflecting in part the low base effects, CPI inflation for 2010 is projected to average between $2.5 \%$ and $3.5 \%$, before moderating next year.

\section{Macro Policy Responses}

3.1 When Singapore entered the recession in 2008, monetary policy, followed by fiscal policy, shifted to provide support to the domestic economy. As economic activity recovered swiftly in 2009, most of the countercyclical measures were withdrawn, and monetary and fiscal policy settings were recalibrated to that which is conducive to sustainable growth and medium-term price stability. In April 2010, the Monetary Authority of Singapore (MAS) tightened monetary policy by re-centring the S\$NEER (Singapore dollar nominal effective exchange rate) policy band upwards and restoring its modest and gradual appreciation path. There is considerable flexibility embedded in the "band" and "crawl" features of Singapore's exchange rate-centred monetary policy framework that would accommodate a sudden shift in economic conditions. The authorities are alert to developments in the external economic environment and domestic prices, including those in the property market. The authorities have a range of tools at their disposal and have in fact deployed some measures to preemptively curb excesses and promote stable and sustainable conditions in the property market.

\subsection{At the same time, fiscal policy has contributed in a significant way to the required} adjustments in the overall macroeconomic stance. With the recovery in economic conditions, the government announced exit strategies late last year for two key components of last year's Resilience Package - the Jobs Credit Scheme and the Special Risk-Sharing Initiative (SRI). The gradual phase-out of these extraordinary measures allows the economy sufficient leadtime to transit into the longer term stance of FY2010 Budget. In the FY2010 Budget, the focus shifted from crisis relief measures to restructuring the economy through investments in skills, building capabilities and encouraging innovation. The government's measures followed from the recommendations of the Economic Strategies Committee (ESC), aimed especially at shifting the economy towards productivity-driven growth. Further, in line with the aim of achieving inclusive and broad-based growth, the Budget contained measures to spur the upgrading of the workforce, higher levies for unskilled foreign labour, additional transfers for low-wage workers to improve income security, as well as the introduction of a progressive property tax system. 
3.3 Singapore's financial system proved to be resilient during the global crisis. The banking system and insurance sector remained profitable, liquid and well-capitalised. The authorities remain vigilant of developments in Europe as well as potential implications from the uneven pace of global recovery and still abundant liquidity conditions. MAS continues to focus financial institutions' attention on managing risks and safeguarding the robustness of their liquidity, earnings and capital. MAS also contributes to ongoing regulatory reform discussions at various international fora. Domestically, it has proposed rules to strengthen the corporate governance of financial institutions, and to improve safety net arrangements such as the deposit insurance fund and the policy-owners protection fund.

\section{$4 \quad$ Structural Issues}

\section{Accumulation of Foreign Assets}

\subsection{Singapore's accumulation of foreign assets reflects the dynamics of demographic} transition and a combination of factors specific to Singapore - very small size, absence of natural resources, and its status as an open financial centre. Given Singapore's small size, investments by Singapore-based enterprises also take place externally. This is complicated by the limited degree of financial integration within Singapore's natural hinterland, thus requiring domestic savings to finance investment abroad. These factors, together with the need for a buffer against volatility in an economy heavily exposed to capital flows, have led to a significant stock of official reserves.

\section{$\underline{\text { Social Safety Nets }}$}

4.2 The authorities are raising government spending so as to invest in the country's capabilities, while addressing the higher social expenditure needs of an ageing society and one facing growing income gaps. The authorities are meeting these needs in a way that preserves the principle of fiscal responsibility and in keeping with a new framework for equitable sharing of the returns from the country's reserves between current and future generations of Singaporeans. In this regard, the Constitution was amended in 2008 to allow the authorities to draw on more investment returns for public sector spending. The authorities are spending more on healthcare and social safety nets including the Workfare Income Supplement scheme and various social assistance or community support programmes, while continuing to incentivise personal and family responsibility. In addition, the returns paid by the Central Provident Fund Board (CPFB) to its members compare well with equivalent market-based instruments, as exemplified by the experience in the recent crisis. ${ }^{1}$

\footnotetext{
${ }^{1}$ From 1 Jan 2008, CPF interest rates were restructured to provide a return equal to 10-year Singapore Government Securities (SGS) plus 1\% for savings in the Special, Medisave, and Retirement Accounts, this being an approximation of returns on equivalent long-term bond instruments. Further, an additional $1 \%$ return above this long-term bond rate is provided for the first $\mathrm{S} \$ 60,000$ of a member's combined balances. Throughout the financial crisis, CPFB also continued to pay a minimum of $2.5 \%$ p.a. for savings in the Ordinary Account, and a minimum of $4.0 \%$ for savings in the Special, Medisave, and Retirement Accounts.
} 


\section{$5 \quad$ Final Remarks}

5.1 Given its openness, the Singapore economy was hard hit during the severe global downturn. Conversely, with the pick-up in the global economy, the Singapore economy rebounded swiftly, supported by policy measures put in place during the downturn. As a consequence, the authorities have exited from the short-term accommodative policy settings and focused on policies to sustain growth over the medium term. Nonetheless, the authorities are mindful of the risks in the global economy. The authorities will closely monitor developments in the external environment and will respond as appropriate.

5.2 The Singapore authorities are pleased to inform the Board that they are agreeable to the publication of the Staff Report associated with the 2010 Article IV Consultation and will be releasing the Buff Statement at the same time. 